San Jose State University

SJSU ScholarWorks

Master's Theses

Master's Theses and Graduate Research

1991

\title{
Facial anatomy of the Harbor Porpoise (Phocoena phocoena) and Dall's Porpoise (Phocoenoides dalli)
}

Barbara Edith Curry

San Jose State University

Follow this and additional works at: https://scholarworks.sjsu.edu/etd_theses

\section{Recommended Citation}

Curry, Barbara Edith, "Facial anatomy of the Harbor Porpoise (Phocoena phocoena) and Dall's Porpoise (Phocoenoides dalli)" (1991). Master's Theses. 105.

DOI: https://doi.org/10.31979/etd.evkq-q2ff

https://scholarworks.sjsu.edu/etd_theses/105

This Thesis is brought to you for free and open access by the Master's Theses and Graduate Research at SJSU ScholarWorks. It has been accepted for inclusion in Master's Theses by an authorized administrator of SJSU ScholarWorks. For more information, please contact scholarworks@sjsu.edu. 


\section{INFORMATION TO USERS}

This manuscript has been reproduced from the microfilm master. UMI films the text directly from the original or copy submitted. Thus, some thesis and dissertation copies are in typewriter tace, while others may be from any type of computer printer.

The quality of this reproduction is dependent upon the quality of the copy submitted. Broken or indistinct print, colored or poor quality illustrations and photographs, print bleedthrough, substandard margins, and improper alignment can adversely affect reproduction.

In the unlikely event that the author did not send UMI a complete manuscript and there are missing pages, these will be noted. Also, if unauthorized copyright material had to be removed, a note will indicate the deletion.

Oversize materials (e.g., maps, drawings, charts) are reproduced by sectioning the original, beginning at the upper left-hand corner and continuing from left to right in equal sections with small overlaps. Each original is also photographed in one exposure and is included in reduced form at the back of the book.

Photographs included in the original manuscript have been reproduced xerographically in this copy. Higher quality 6" x 9 " black and white photographic prints are available for any photographs or illustrations appearing in this copy for an additional charge. Contact UMI directly to order.

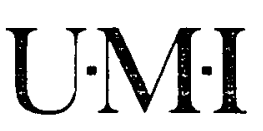

University Microfilms international

A Bell \& Howell information Company

300 North Zeeb Road. Ann Arbor. MI 48106-1346 USA

$313 / 761-4700 \quad 800 / 521-0600$ 

Facial anatomy of the harbor porpoise (Phocoena phocoena) and Dall's porpoise (Phocoenoides dalli)

Curry, Barbara Edith, M.S.

San Jose State University, 1991 

FACIAL ANATOMY OF THE HARBOR PORPOISE (Phocoena phocoena)

AND DALL'S PORPOISE (Phocoenoides dalli)

\author{
A Thesis \\ Presented to \\ The Faculty of Moss Landing Marine Laboratories \\ San Jose State University \\ In Partial Fufillment of the \\ Requirements for the Degree \\ Master of Science in Marine Science
}

by

Barbara Edith Curry

May 1991 


\section{APPROVED FOR THE DEPARTMENT OF MOSS LANDING MARINE LABORATORIES}
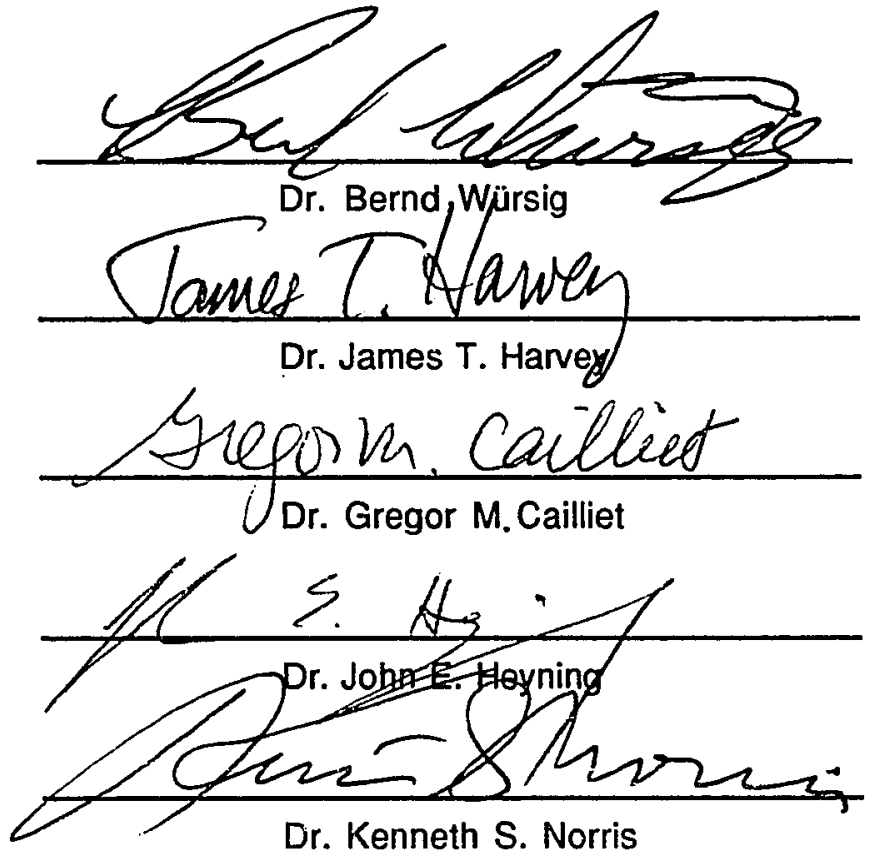

Dr. Kenneth S. Norris

APPROVED FOR THE UNIVERSITY 
To my mom and to the memory of my dad.

They showed me that the world is a place of wonderment. 


\begin{abstract}
Structural modifications of the odontocete skull and nasal passages have shifted the position of the facial bones and associated soft anatomy to the dorsal aspect of the head. The facial structures of true porpoises, Phocoenidae, are highly specialized. To describe the facial anatomy of phocoenid cetaceans and to examine its functional significance, facial regions of 18 Phocoena phocoena and three Phocoenoides dalli specimens were dissected and compared to facial regions of 10 specimens representing five delphinid species. In addition, heads of three phocoenid specimens were serial sectioned. Nasal passages, associated diverticula, and facial muscles of these phocoenid species are described, and are considered to be homologus to facial structures of delphinids with several notable exceptions. The blowhole ligament and its posterior septum appear to be separate branches of the same structure; the blowhole ligament of delphinids may be a derived condition associated with the loss of the posterior septum. Nasal sac calculi found in two Phocoenoides dalli specimens and three Phocoena phocoena specimens were analysed with Scanning Electron Microscopy. Calculi of one Phocoenoides dalli specimen were composed of $100 \%$ apatite, and calculi of one Phocoena phocoena specimen were composed of $80 \%$ calcium carbonate and $20 \%$ apatite. Hisiological samples of nasal diverticula of Phocoena phocoena specimens revealed stratified squamous epithelial surfaces with dermal papillae developed to varying degrees. Functional capabilities of phocoenid facial structures supports current evidence of their use in respiration and sound production.
\end{abstract}




\section{Contents}

Page

Introduction ......................................................................................... 1

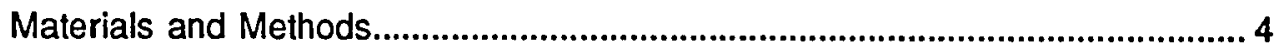

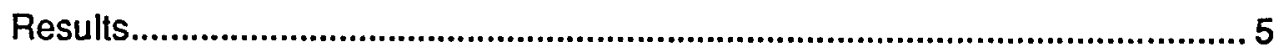

General Description of Odontocete Facial Anatomy.....................................5

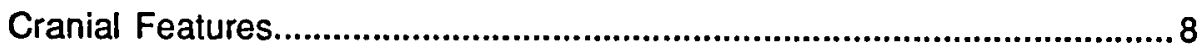

Phocoena phocoena.............................................................................. 8

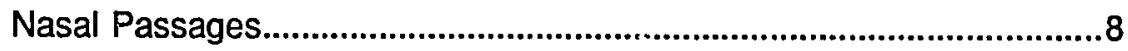

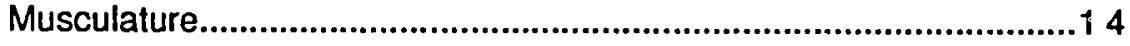

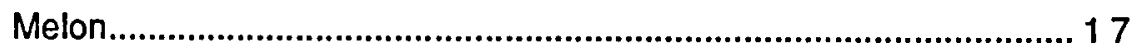

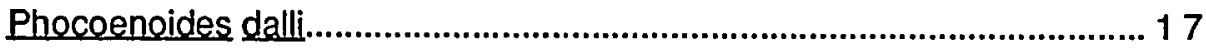

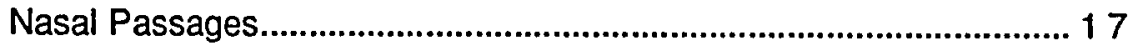

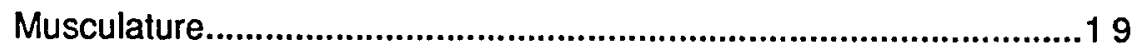

Size of Nasal Structures.................................................................... 2 ?

Histology of Phocoenid Nasal Structures................................................. 21

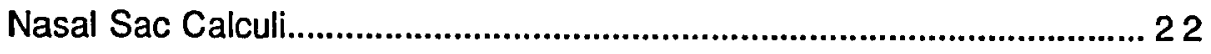

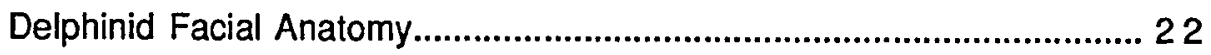

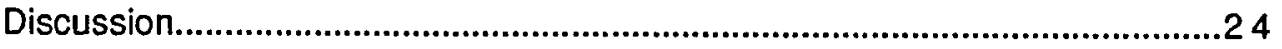

Comparison of Phocoenid and Delphinid Facial Anatomy..........................2 24

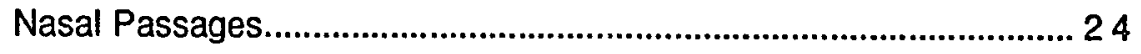

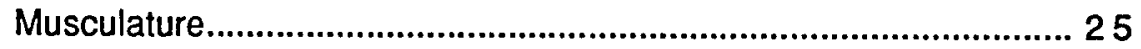

Nomenclature of the Blowhole Ligament and Posterior Septum............... 27

Histology of Phocoenid Nasal Structures.............................................. 28 


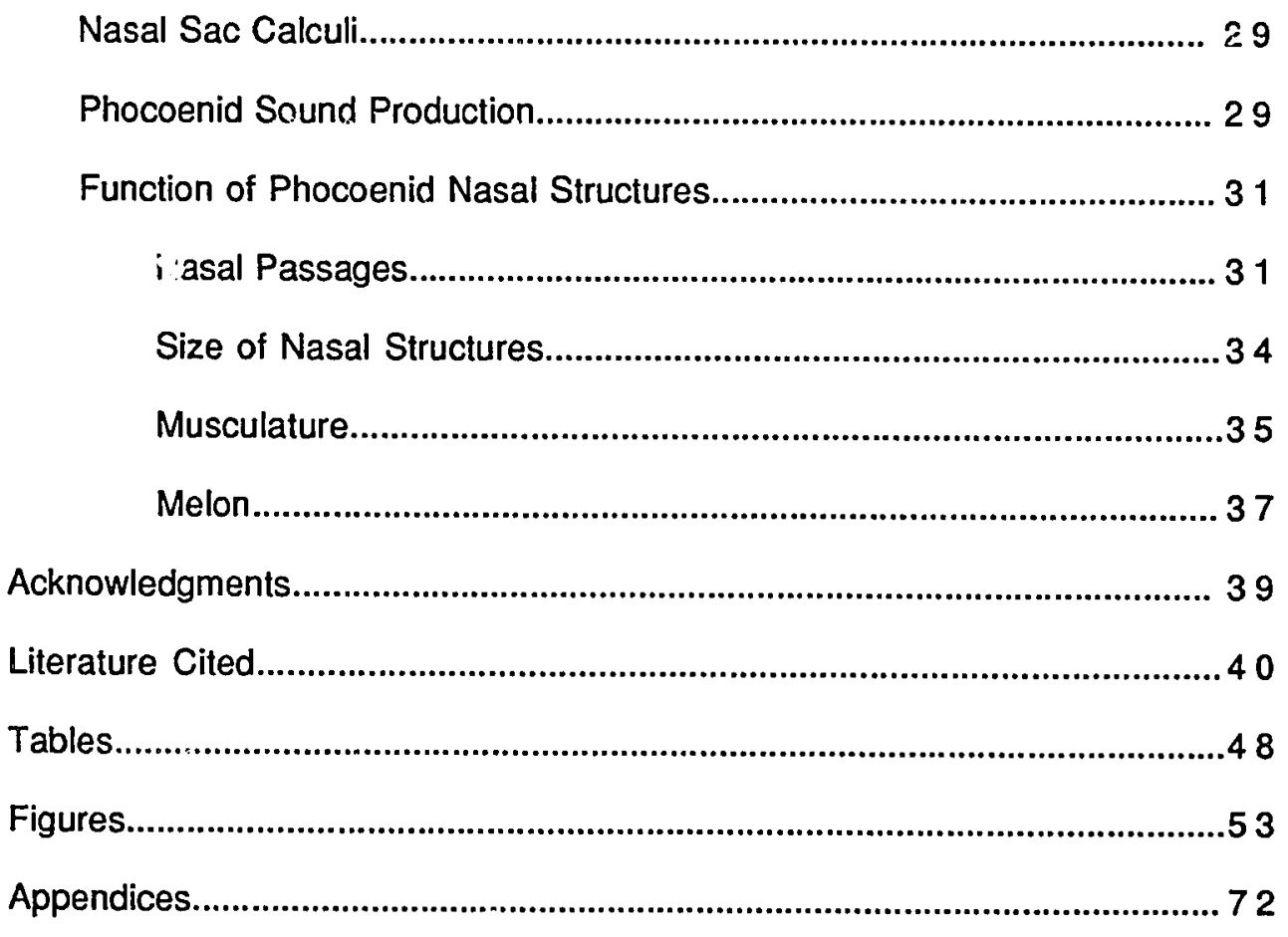


"Apart from all speculation, the blow-hole of the Porpoise, forming a part of its mechanism of respiration, must in itself be regarded as one of the most intricate and nicely adjusted apparatus that has yet been observed."

F. Sibson (1848:121)

\section{INTRODUCTION}

Evolutionary modifications of the odontocete facial region have resulted in a specialized anatomical system which facilitates air movement thioughout the nasal passages. These modifications include the posterior migration of the nares and telescoping of cranial elements, such as the elongation of the maxillae and premaxillae to extend posteriorly over the cranium (Miller, 1923; Barnes and Mitchell, 1978). With these changes, unique structural adaptations of the nasal passages have occurred. Complex diverticula, soft tissue structures, and muscle layers have developed into an interrelated system adapted for respiration and sound production (Mead, 1975; Heyning and Mead, 1990).

The monophyletic order Cetacea includes both the Odontoceti, or toothed whales, and the Mysticeti or baleen whales (see Barnes et al., 1985). In their taxonomic treatment of the Cetacea, Barnes et al. (1985) list four superfamilies among the exiant species of odontocetes. These include the platanistoids (river dolphins), delphinoids (dolphins and porpoises), ziphioids (beaked whales), and the physeteroids (sperm whales). The odontocetes are a diverse group with sixty six species currently recognized (Perrin, i 989$)$.

Significant differences in facial anatomy exist within the Odontoceti, and there are differences in the sound signals produced among odontocetes. Thus, comparison of specific facial structures is useful for functional and phylogenetic analysis. Lawrence and Schevill (1956) and Mead (1975) presented detailed descriptions of delphinid facial anatomy with a nomenclature useful from both structural and functional perspectives. Recently, Heyning (1989) compared facial anatomy of the beaked whales with other odontocetes using this nomenclature. In this paper he also completed an extensive treatment on the homologies of odontocete facial structures.

The facial anatomy of the true porpoises, family Phocoenidae, is highly specialized. 
This anatomy has been described by many workers, particularly for the harbor porpoise (Phocoena phocoena). In his classic description of harbor porpoise, Von Baer (1826) presented the fundamental elements of phocoenid facial anatomy. His description formed the comparative basis for the works of Kükenthal (1893), Gruhl (1911), and Rawitz (1900). Kükenthal (1893) examined the ontogeny of $P$. phocoena facial structures, and presented detailed descriptions and figures of the nasal passages. Developmental aspects of these structures and homologies with delphinid facial anatomy were also discussed by Gruhl (1911). Rawitz (1900) described the facial anatomy of $P$. phocoena, referring not only to the earlier works of von Baer (1826) and Kükenthal (1893), but also to Murie's (1870) description of delphinid facial anatomy, to create a useful system of nomenclature that considers the location, as well as function, of nasal structures.

The function of harbor porpoise facial anatomy for respiration is often discussed in earlier publications. Sibson (1848) presented a general description of harbor porpoise nasal sacs and musculature with reference to their function in respiration and buoyancy. Recognizing that the complex nasal passages must have developed for something other than respiration alone, Sibson (1848) suggested that the nasai sacs can systematically inflate for buoyancy control.

More recent works include a study of the porpoise head (Moris, 1969), which discussed the facial anatomy briefly. Schenkkan (1973) used $\mathrm{P}$. phocoena as the comparative species in his accounts of odontocete nasal anatomy. The definitive monograph by Mead (1975) on the facial anatomy of the Delphinidae included a description of $P$. phocoena, as did the work of Heyning (1989).

Fewer studies have surveyed the facial anatomy of the remaining phocoenid species. Ridgway (1966) described the vestibular sacs of Dall's porpoise (Phocoenoides dalli); Mead (1975) and Heyning (1989) also commented on this species. The nasal passages and diverticula of the spectacled porpoise (Australophocaena dioptrica) were described by Gallardo (1913). Howell (1927) described this anatomy for the finless porpoise (Neophocaena phocaenoides), and recently Gao and Zhou $(1988,1989)$ studied the nasal passages and nasal musculature of this species. The architecture of the nasal 
musculature of three specimens was investigated by Gao and Zhou (1989), and the potential force of muscle contraction was calculated. Detailed descriptions of the musculature have not been published for most species of this family.

Barnes (1985) recognized two subfamilies (Phocoeninae and Phocoenoidinae) for the six species within the Phocoenidae (Delphinoidea). The Phocoeninae contains the extant species Phocoena phocoena, Phocoena spinipinnis (Burmeister's porpoise), Phocoena sinus (vaquita, Gulf of California harbor porpoise), and Neophocaena phocaenoides. Included within the Phocoenoidinae are the extant species Australophocaena dioptrica, and Phocoenoides dalli. This division is based on evidence from the fossil record and from extant species, with particular reference to cranial features. Phocoenoidinae possess larger adult body sizes than members of Phocoeninae, a vertically elevated occipital shield, a steep incline of the facial fossa approaching the vertex posterior to the bony nares, and a relatively broad vertex (Barnes, 1985).

There have been two major hypotheses regarding the anatomical source of sounds produced by odontocetes. One hypothesis proposes that the larynx acts as the sound production source (Purves, 1967). Odontocetes do not possess vocal cords, but the larynx is structurally complex with elongate arytenoepigiottid cartilages and laryngeal tissue folds (Lawrence and Schevill, 1965). These laryngeal folds once were thought to be vocal cords (Murie, 1870:Fig. 2). Reidenberg and Laitman (1988) examined 10 odontocete genera, and defined the laryngeal folds as "vocal folds" homologous with mammalian vocal cords. The authors further suggested that the vocal folds can be vibrated by air movement directed dorsaliy from the trachea.

The second proposed site of sound production is the nasal passage and associated diverticula (Lilly and Miller, 1961; Evans and Prescott, 1962; Norris, 1964, Norris et al., 1971). Ridgway et al. (1980) presented data for Iursiops truncatus (bottlenose dolphin) based on electromyographic and pressure events demonstrating that the nasal system, and not the larynx, is functional during sound production. An increased pressure was observed in the nares preceding vocalizations, but no intratracheal 
pressure change occurred. Nasal muscles fired before and during vocalizations, h;oepiglottal and intercostal muscles did not (Ridgway et ai., 1980). This information has been supplemented by experiments on P. phoceena (Amundin and Andersen, 1983) and an actively echolocating beluga whale Delphinapterus leucas (Ridgway and Carder, 1988).

The primary objective of this study was to describe the facial anatomy of $P$. phoceena and $\mathrm{P}$. dalli, and to compare it with the facial region of delphinid species. These results are useful for examining the functions of phocoenid facial anatomy based on recent studies of odontocete sound production (Ridgway et al., 1980; Amundin and Andersen 1983; Ridgway and Carder, 1988; for review see Heyning, 1989).

\section{MATERIALS AND METHODS}

Detailed dissections of the facial region were performed on 18 specimens of $P$. phocoena and three of $\mathrm{E}$. dalli. The three-dimensional aspects of odontocete facial anatomy were examined using gross dissection and serial sectioning at sagittal, transverse, and coronal planes. Serial sections were made of two frozen heads of $P$. phocoena and one of $\mathrm{E}$. dalli (Fig. 1). Sections were placed in $10 \%$ buffered formalin prior to examination.

A series of measurements were obtained from the nasal diverticula and associated structures (Appendices 1 and 2). To test the null hypothesis that there was no relationship between size of nasal structures and body length of $\mathrm{E}$. phocoena, these measurements were plotted against standard body length using a simple linear regression.

To determine tissue siructure, histological samples were collected for each of the nasal diverticula (Table 1). Tissue samples were fixed in $10 \%$ buffered formalin or $6 \%$ buffered glutaraldehyde before sectioning. Tissue slides were prepared by Histo-Tec Laboratory, Hayward, California.

When present, nasal sac calculi were collected from specimens. Crystallographic analysis of the concretions in two specimens was confirmed by Scanning Electron 
Microscopy, and completed by the University of California, Davis-Urinary Stone Analysis Laboratory.

The facial regions of several delphinid species, 10 specimens, were dissected for comparison with phocoenids. Specimens of $I$. truncatus were included because the species is widely studied and formed the comparative basis of Mead's (1975) paper.

Specimens available for this study were preserved by freezing and are listed in Table 1. Photographs, drawings, and detailed notes were taken at each dissection.

\section{RESULTS}

\section{General Description of Phocoenid Facial Anatomy}

A general description of phocoenid facial anatomy combined with currently accepted nomenclature is useful to orient the reader to the complex configurations of the nasal passages and associated musculature. Structural modifications of the odontocete skull and nasal passages have shifted the facial bones and related soft anatomy to the dorsal surface of the head (Fig. 2). Hence, the external naris or blewhole is located there as well. The nasal passage or spiracular cavity leads ventrally from the surface to the bony nares, which is divided by a bony septum into two passages within the cranium. In phocoenids, four pairs of diverticula extend from the nasal passage (Fig. 3).

The most superficial nasal sacs are the vestibular sacs (Lawrence and Schevill, 1956). These large sacs extend anterolaterally from the nasal passage. Each sac has a small, circular opening or aperture (Sibson, 1848) at the anterior wall of the nasal passage.

Beneath the vestibular sacs are the nasofrontal sacs (Murie, 1870) (Figs. 3 and 4). The nasofrontal sacs are large and complex, extending along a transverse plane to form a semicircle around the nasal passage. The sacs have an anterior and posterior aspect in relation to the nasal passage, and the curved portion of the right and left sac around the lateral edges of the passage is called the angle (Mead, 1975). Present in many delphinid species, but not always in phocoenids (see Schenkkan, 1973), is a small accessory sac located at the lateral aspect of the head, below and slightly posterior to, the angles of the 
nasofrontal sacs. The posterior nasofrontal sacs open ventrally to communicate with the rest of the nasal passage through the inferior vestibules.

The inferior vestibules (Gallardo, 1913) are small cavities or chambers, which are formed against the surface of the cranium at the nasal bones. Posterior to the nasofrontal sacs, are the pesterior nasal sacs (Moris, 1969; see Heyning, 1989).

These sacs are dorsal to the inferior vestibules, and open to them ventrally (Figs. 3 and 4).

The posterior nasofrontal sacs and posterior nasal sacs are separated by bilaterally paired connective tissue septa within the inferior vestibules. These are the posterior septa of the blowhole ligaments (new term). The posterior septa originate, along with the blowhole ligaments (Lawrence and Schevill, 1956), at the mesethmoid and nasal bones and extend laterally to the external edge of the bony nares (Fig. 5).

The premaxillary sacs (Murie, 1870) of phocoenids are small, and extend anteriorly a short distance dorsal to the premaxillary bone. The premaxillary sacs open to the anterior wall of the nasal passage, at the level of the bony nares. Bordering the posterior margin of the bony nares, are the small diagenal membranes (Lawrence and Schevill, 1956).

Dorsal to the blowhole ligaments are the elliptical bedies (Mead, 1975). There are four of these structures, one dorsal to each of the blowhole ligaments, and one immediately dorsal to each nasal plug lip.

The nasal plugs (Lawrence and Schevill, 1956) are paired connective tissue structures that extend posteriorly from the anterior wall of the nasal passage, to occlude the passage. The nasal plug muscles (Lawrence and Schevill, 1956) extend anteriorly from the plug lips, and are the dorsal surface of the premaxillary sacs.

The melon is composed of adipose tissue and connective tissue fibers, and is anterior to the nasal passages, dorsal to the anterior portion of the maxillary and premaxillary bones (rostrum). It is covered with dermal connective tissue. Several muscle layers grade into the ventral and lateral surfaces of the melon.

Intrinsic muscles (Lawrence and Schevill, 1956) enclose the nasofrontal sacs and the 
posterior nasal sacs. These intrinsic muscles have no clearly defined fiber orientation, and are permeated with connective tissue. In phocoenids, there is also a well defined vestibular sac intrinsic muscle (Mead, 1975; but see discussion) which does not contain connective tissue.

Beneath the hypodermal layer, and superficial to the facial musculature, a wide band of connective tissue fibers extends from the vertex to the lateral rostral musculature.

This is the superficial facial band of fibers (new term).

Following the muscle patterns described by Lawrence and Schevill (1956) and Mead (1975) there are four layers of facial muscle in phocoenids (Fig. 6). The superficial layer is the pars intermedius. Deep to the pars intermedius is the broad pars anteroexternus. The deep muscle layers include the pars posterointernus and the pars anterointernus. Forward of the antorbital notch, fibers of the pars anterointernus are defined as the rostral musculature. This muscle is divided into lateral and medial portions (Mead, 1975).

Von Baer (1826) noted that each of the muscle layers seem to be continuous with the next, possibly all one muscle. Similarly, delphinid facial muscles are continuous with one another (Lawrence and Schevill, 1956; Mead, 1975; Heyning, 1989). Huber (1934) proposed that delphinid facial muscles are homologous with the pars nasalis and the pars labialis of the $\mathrm{m}$. maxillonasolabialis of terrestrial mammals. Accordingly, he divided them into anterior (pars labialis) and posterior (Rars nasalis) portions. Mead (1975) was in agreement with this suggestion, but considered the lateral rostral muscle and superficial muscle layers to be derivatives of the pars labialis and the medial rostral muscle and the pars anterointernus to be derivatives of the pars nasalis of the $\mathrm{m}$. maxillonasolabialis. Among terrestrial mammals, the $\mathrm{m}$. maxillonasolabialis originates from the maxilla and passes anteriorly or anteroventrally to insert upon the nose or lips, and often is separated into two or more distinct muscle layers (von Boas and Paulli, 1908; Edgeworth 1935). 


\section{Cranial Features}

Asymmetry is evident in certain cranial characters of $\mathrm{P}$. phocoena and $\mathrm{P}$. dalli. Miost obvious is the slightly wider premaxillary eminence on the right side of the skull. The nasal bone also is broader on the right side than on the left. The bony nares and vertex are offset to the left, a characteristic which may be associated with the larger diameter of the bony naris on the left side. A sinus that extends dorsally between the anterior face of the frontal bone and the ventral face of the maxillary bone is visible sagittal and coronal serial sections (Fig. 7). This is a branch of the pre-orbital lobe of the pterygoid sinus described by Fraser and Purves (1960), and the cavity of this sinus can also be seen on a complete skull.

A portion of the maxilla forms the posterior wall of the inferior vestibule, and the nasal bones comprise the posterior wall of the posterior nasal sass. The posterior wall of the inferior vestibule is covered by periosteum and epithelium, and forms a smooth, concave basin that is vertically oriented. The basin leads past the edge of the posterior terminations of the premaxillae and the bony nares, to the lateral aspect of the premaxillary eminence which is occupied by the premaxillary sacs. This basin is larger on the right side (Fig. 8).

\section{Phocoena phocoena}

\section{Nasal Passages}

The blowhole is crescent shaped, but is not strongly curved in this species. The apices turn anteriorly; the right side usually extends a few millimeters further anteriorly than the left. The blowhole is slightly left of the longitudinal axis, and is located approximately 2.5 to $3.0 \mathrm{~cm}$ anterior to the vertex of the skull.

The spiracular cavity or nasal passage is immediately ventral to the blowhole, and is pliable with thin walls of darkly pigmented epithelium. The superficial portion of the spiracular cavity is directed anteriad at an approximate $45^{\circ}$ angle to the deeper passage. Approximately $1.5 \mathrm{~cm}$ cieep to the blowhole, the walls of the spiracular cavity are firm, composed of connective tissue, and lined with the pigmented epithelium. The spiracular 
cavity is 2symmetrical, with the right side extending laterally slightly further than the left. Deep to the spiracular cavity, the nares are separated by a cartilaginous septum. Within the skull the internal nares are two separate passages.

The paired vestibular sacs are larger in phocoenids than delphinids. Total width of the sacs ranged from 8.6 to $10.3 \mathrm{~cm}(n=4, \bar{x}=9.2, S D=0.75)$; total length of the right sac ranged from 4.2 to $5.3 \mathrm{~cm}(n=4, \bar{x}=4.9, S D=0.48)$; total length of the left sac ranged from 3.3 to $5.0(n=4, \bar{x}=4.4, S D=0.78)$ in adults. Total width of vestibular sacs in immature specimens ranged from 8.0 to $8.9(n=5, \bar{x}=8.5, S D=0.39)$; total length of right sac ranged from 3.8 to $4.2(n=5, \bar{x}=4.0, S D=0.21)$; total length of left sac ranged from 2.9 to $3.4(n=5, \bar{x}=3.2, S D=0.23)$.

The sacs extend in an anterior direction from the nasal passage. The entrance to the vestibular sacs has a transverse orientation, and is located approximately $1.5 \mathrm{~cm}$ deep to the blowhole. Within the narrow entrance are the bilaterally paired apertures of the sacs (Heyning and Mead, 1990).

Anteriorly, a small part of each sac is dorsal to the posterior tip of the melon. Loosely bound within the vestibular sac intrinsic muscle, the sacs are held in contact with one another medially. The thick fold of muscle (pars anteroexternus and pars anterointernus), which encloses the sacs laterally, maintains constant tension on them. The vestibular sacs are triangularly shaped and follow the general contour of the maxillary bone.

The dorsal surface of the vestibular sac is thin and wrinkled, much like the delphinid vestibular sac. The ventral surface of the sac is composed of a thick connective tissue that is deeply plicate (Niorris, 1964), and lined with darkly pigmented epithelium (Fig. 9). The plica are concentrically arranged around a central opening or division, which was termed the "hendidura central" by Gallardo (1913:Fig. 3). This central division, as well as the plica, leads to the aperture of the vestibular sac. The circular aperture is formed by the most medial terminations of the vestibular sac plica, at the proximal end of the sac.

The deep nasal sacs include the nasofrontal sacs, posterior nasal sacs, and 
premaxillary sacs. Total width of nasofrontal sacs ranged from 6.0 to $6.7 \mathrm{~cm}$ in adult specimens $(n=4, \vec{x}=5.8, S D=0.17)$, and from 5.3 to $6.2 \mathrm{~cm}$ for immatures $(n=3, \bar{x}=$ $5.9, \mathrm{SD}=0.49$ ). The anterior component of the nasofrontal sac in $\mathrm{P}$. phoceena is hypertrophied, and expands dorsally. The right anterior nasofrontal sac is larger than the left, and its dorsal expansior: is proportionally larger as well. Medially, the terminations of the right and left anterior components are in contact with each other in most specimens. In 15 of the 18 specimens dissected, a small bifurcated outpocketing at the anterolateral aspect of the right anterior component was observed. At approximately the angle of the nasofrontal sac, each side has a small posterolateral extension that ends blindly. This extension is usually more prominent on the right sac, and is probably the homologue to the delphinid accessory sac.

Many nodules and tiny diverticula (lobules) are present on the external surface of the anterior nasofrontal sacs (Fig. 10). The lobules are particularly noticeable at the blind ends of the sacs. There are more lobules on the end of the right anterior component than on the left. The anterior nasofrontal sacs are lined with a trabeculate epithelium, which contains crescentic pores and appears to be glandular (Mead, 1975). Thick trabeculate epithelium also is found in all outpocketings of the nasofrontal sacs. There is a thick, whitish secretion present in these trabeculated areas. Pigmentation of the anterior nasofrontal sacs is variable, and they often are only partially pigmented.

The posterior component of the nasofrontal sac is continuous with the anterior component, but is compressed against the posterior wall of the nasal passage. The posterior component of the nasofrontal sac is small, usually extending less than $1.0 \mathrm{~cm}$ along the posterior aspect of the blowhole ligament at the mediolateral axis. The posterior nasofrontal sac opens ventrally into the most anterior margin of the inferior vestibule. The posterior nasofrontal sacs usually lack pigmentation.

The posterior nasal sacs are situated dorsal to the inferior vestibule at the nasal bones. The right sac is slightly larger than the left. The mean width of the right sac in adults was $3.0 \mathrm{~cm}(n=4, S D=0.56)$, and $2.6 \mathrm{~cm}$ for the left sac $(n=4, S D=0.57)$ in adults. The posterior nasal sacs of immature specimens had a mean width of 3.5 for the right sac 
$(n=3, S D=0.45)$, and a mean width of 3.0 for the left sac $(n=3, S D=0.25)$

Each sac has a small outpocket that extends lateroanteriorly and ends blindly. At the posterior portion of each sac, the boss of the nasal bone is present below the vertex. The lining of the posterior nasal sac covers the dorsal aspect of the boss creating a small shelf-like pocket that extends medially from the sac. The relatively thick posterior nasal sacs are lined with nonpigmented, trabeculate epithelium. A thick whitish secretion is present in the trabeculated areas. The trabeculated areas also are visible as nodules on the exterior surface of the sacs.

The posterior nasofrontal sacs are separated from the posterior nasal sacs by a pair of dense connective tissue structures, the posterior septa of the blowhole ligament (Fig. 11). Each posterior septum is attached to the cranium by fibrous cartilage at the area of contact between the mesethmoid and nasal bones, posterior to the nasal septum (Fig. 2). Thin fibers extend posteriorly from the septa, to the nasal bones below the vertex. The septum extends laterally to attach to the epithelium of the spiracular cavity at the edge of the nares, and to fibers of a deep muscle layer, the pars pesterointernus. The structure is approximately $2.0 \mathrm{~cm}$ thick and slightly convoluted. The septum is darkly pigmented at its ventral aspect.

A branch of the posterior septum extends into the anterior nasofrontal sac at the angle of the sacs, through the incomplete ventral aspect of the posterior nasofrontal sac (Fig. 11; Appendix). The branch extends for several centimeters, and tapers to a thin point. The right branch was longer in 14 of the 18 specimiens examined. Tissue of this tapered branch of the posterior septum is bound to the lining of the sac, usually along the lateral aspect of the nasofrontal sac angle. The branch effectively (although not completely) divides the sac into two channels. The dorsal expansion of the sac leads to the posterior nasofrontal sac through the more medial channel, and the remainder of the anterior nasofrontal sac leads to the posterolatera! extension of the sac (which conriects to the inferior vestibule) through the lateral channel.

The bilaterally paired blowhole ligaments are located just anterior to the posterior 
septa, and originate at the same region, from the cartilage associated with the mesethmoid and nasal bones and the nasal septum. Medially, at the nasal septum, the leading margin of each ligament consists of an ovoid portion of hyaline cartilage, and connective tissue (Fig. 5). The ligament extends laterally from the cartilage of the nasal septum to the maxilla and the lateral wall of the nasal passage. Fibers of a deep muscle layer, the pars posterointernus, insert upon the distal end of the ligament. The blowhole ligament contains a small, but thick muscle. The muscle is approximately $1.5 \mathrm{~cm}$ long and from 0.3 to $0.5 \mathrm{~cm}$ thick. The body of the muscle is within the lip of the ligament, which is shaped somewhat like the lips of the nasal plugs (see below). This portion of the blowhole ligament is in contact with the shallow floor of the inferior vestibule at the posterior edge of the bony nares.

Cartilages of the nasal septum, mesethmoid and nasal bones, and the blowhole ligament, have complex orientations (Fig. 5). There are paired cartilaginous structures at the anterior aspect of the bony nares which are continuous with the mesorostral cartilage and the cartilaginous septum that I have called the prenarial cartilages. A small pedicle arises posterior to the posterior septum of the blowhole ligament in the median sagittal plane, from the area of contact between the mesethmoid and nasal bones. The pedicle extends dorsaily to the level of the vestibular sac apertures. The tip of this pedicle is a small, approximately $3.0 \mathrm{~mm}$ structure, which is oriented vertically behind the posterior wall of the spiracular cavity, and is covered by a layer of epithelium.

A parasagittal section $1.0 \mathrm{~cm}$ from the center of the head of specimen JTH 054 , illustrates the relationship between the structures in the deeper nasal passage (Fig. 12). The lip of the nasal plug fits against the muscular lip of the blowhole ligament. Also evident in this section is the proximity of the ligament's lip to the ventral opening of the posterior nasofrontal sac. Transverse section number 3 (See Fig. 1) shows the fit of the nasal plug lip and the lip of the blowhole ligament. In this section the lip of the blowhole ligament is directed posteriorly and rests, along with the nasal plug lip, against the periphery of the bony nares.

Immediately dorsal to the blowhole ligaments, are the elliptical bodies described by 
Mead (1975) in delphinids. These are elliptical rods of adipose tissue, approximately $1.0 \mathrm{~cm}$ long, located interior to the anterior and posterior folds described by Lawrence and Schevill (1956).

The nasal plugs are small, with the right side slightly larger than the left. The mean width of the right plug lip was $2.2 \mathrm{~cm}(n=4, S D=0.28)$, and mean width of the left was $1.9 \mathrm{~cm}(n=4, S D=0.26)$ in adult specimens. The mean width of the right plug lip was $2.0 \mathrm{~cm}(n=5, S D=0.24)$, and mean width of the leit was $1.7 \mathrm{~cm}(n=4, S D=0.21)$ for immatures. Whereas the lips of the two sides characteristically have slightly different shapes, there was no prominent lateral extension of the plugs as is typically found in delphinids.

The deepest of the nasal diverticula are the premaxillary sacs, which rest upon the premaxillary eminence. These sacs were relatively small in relation to the more superficial diverticula, with a mean length of the right sac measuring $1.6 \mathrm{~cm}$ in adults $(n=4, S D=0.47)$, and mean length of the left sac was $1.8 \mathrm{~cm}$ for adults $(n=4, S D=$ 0.57). The mean width of the right sac was $1.3 \mathrm{~cm}$ for immatures $(n=4, S D=0.21)$, and $1.3 \mathrm{~cm}(n=4, S D=0.26)$ for immature specimens.

The premaxillary sacs do not extend to the anterior tip of the premaxillary eminence. However, the sacs do occupy the lateral surfaces of the eminence, with the lumens extending to the periphery of the premaxillary bone.

The inferior vestibule is a small chamber which is caudad and dorsad to the internal nares. The posterior wall of the inferior vestibule extends against the cranium, and the blowhole ligament acts as the anterior wall. The chamber opens dorsally into the posterior nasal sac, as well as into the posterolateral extension of the nasofrontal sac. The latter opening is partially occluded by the posterior septum, which occupies the vestibule.

The bilaterally paired diagonal membranes are located at the posterolateral edge of the bony nares. The membranes are folds of epithelial tissue with a few connective tissue fibers and muscle fibers. The right membrane is larger, and has greater amounts of muscle fiber than the left. The diagonal membranes are less than $5.0 \mathrm{~mm}$ wide. 


\section{Musculature}

Beneath the epidermal layer, dermal connective tissue covers the anterior aspect of the facial region, and extends posterolaterally to the level of the blowhole where it intergrades with the hypodermis. Posteriorly, there is a hypodermal layer similar to that of the rest of the body. Subdermal fat deposits, associated with the vertex and connective tissue fibers, are found posterior to the rostrum. These rat deposits also extend below the superficial muscle layer near the posterior portion of the vestibular sac.

The superficial facial band of connective tissue fibers extends from the vertex, and from a small area of the nuchal crest, to the lateral rostral muscle at the level of the antorbital notch. The band is 3.0 to $4.0 \mathrm{~cm}$ wide and passes over the posterior part of the vestibular sac. The lateral rostral muscle is bound to the band by a thin sheet of fascia. In this region, the band grades into connective tissue fibers of the blubber. In most specimens, a few fibers diverge in a ventral direction, and are attached to the supraorbital process slightly posterior to the eye. (Fig.13)

The band of fibers is heavily invested with adipose tissue that is found both above and below it. In some specimens, muscle tissue was observed in the fibrous band. Posteriorly, near the vertex, the band becomes tendinous and is easily separated from the layer of fat beneath it. The anterior portion of the band is more difficult to separate because muscle and connective tissue fibers of the dermis merge with it.

The superficial muscle layer originates along the temporal and nuchal crests, and sometimes along a portion of the frontal bone (Fig. 6a). The fibers are anteriorly directed. Posteromedially, near the vertex, a small part of the muscle inserts upon the lateral edge of the nasal passage. Some fibers insert ventral to the vestibular sac, onto the fascia of the pars anteroexternus. Most of the muscle, however, passes over the vestibular sac and inserts into the dense connective tissue of the melon. A variable amount of fibers insert onto the intrinsic muscle that surrounds the vestibular sac. The muscle is tendinous at the posterior portion of the vestibular sac. This muscle is homologous with the pars intermedius of delphinids. 
The pars anteroexternus lies deep to the pars intermedius and originates from the supraorbital process, temporal crest, and the maxilla Fig. 6b). The pars anteroexternus is wide, but relatively thin with the exception of its anterior portion. Fibers of the pars anteroexterrus gradually change orientation from the anteriorly directed fibers at the posterior aspect, to medially directed fibers forward of the temporal crest.

The posteromedial fibers of the pars antereexternus insert upon the posterior edge of the nasal passage. These fibers are difficult to separate from fibers of the pars intermedius. A few fibers of the pars anteroexternus insert around the thin lateral and anterior walls of the upper nasal passage. Other fibers of the muscle insert upon the aperture of the vestibular sac. The posterior most of those fibers insert upon the lateral and dorsal aspects of the aperture, while anterior fibers insert on the ventral aspect of the sac and aperture. The most anterior fibers of the pars anteroexternus insert ventral to the vestibular sac, onto the connective tissue anterior to the nasal passage, and then fold over the sac. Here, the pars anteroexternus merges with the underlying pars anterointernus, and creates a thick fold of muscle which encloses the anterior half of the vestibular sac. The two muscles become continuous with the intrinsic muscle of the vestibular sac.

Deep to the pars anteroexternus, the pars posterointernus is a small muscle with strong origins from the maxilla at the posterior region of the facial fossa (Fig. 6c). The muscle forms an aponeurosis with the deeper fibers of the pars antereexternus at its insertion into the connective tissue and intrinsic muscle of the posterior nasal sac, and the connective tissue that surrounds the lateral aspect of the nasofrontal sac. Some fibers of the pars posterointernus insert ventral to the lateral aspect of the nasofrontal sacs onto the lateral portions of the posterior septum and the biowitioile ligament. These fibers continue anteriorly to insert into the fold of the posterior nasofrontal sac onto the posterior wall of the nasal passage at the elliptical bodies.

The deepest facial muscle is the pars anteroiniernus (Fig. 6c). This muscle is thick and has a broad origin on the maxilla. The posterior fibers insert onto the connective 
tissue surrounding the nasofrontal sac. Fibers of the pars anterointernus also insert at the lateral aspect of the nasal passage. Anterior fibers insert into the connective tissue anterior to the nasal passage. The most anterior fibers merge with the pars anteroexternus, and enclose the vestibular sac.

Rostral muscles originate along the maxillae. The lateral rostral muscles originate from the lateral edge of maxillae and insert into the dermal connective tissue of the lips and of the lateral aspect of the melon. The medial rostral muscles originate from the dorsal surface of the maxillae, with only a few fibers originating from the premaxillae, and insert into the melon.

The following description of specimen NAB 010 is representative of this species. Anteriorly, $2.0 \mathrm{~cm}$ from the rostrum tip, there is a predominance of lateral rostral muscle. At $8.0 \mathrm{~cm}$ from the tip, approximately the middle of the rostrum, medial rostral muscle is more evident as the melon becomes exposed. Both lateral and medial rostral muscles are very thick at $10.0 \mathrm{~cm}$ from the rostrum tip, several centimeters anterior to the nasal passage. There is litile evident asymmetry of the rostral muscles (Fig. 14).

Between the point of origin and the point of insertion into the ventral surface of the melon, medial rostral muscle fibers lie dorsal to a transverse sheet of loose connective tissue which covers the mesorostral (ethmoid) canal and most of the premaxillae. A few fibers may insert on this tissue, but muscle fibers do not originate in this region.

The vestibular sac intrinsic muscle surrounds the sacs and has no distinct fiber orientation. The muscle loosely binds the paired sacs together at the tip of their medial aspect (Fig. 15). At this point (medially), the fibers from the intrinsic muscle of each sac are joined by fascia. The muscle appears to be continuous with the anterior fold of the pars anteroexternus and the pars anterointernus.

The intrinsic muscles of the nasofrontal and posterior nasal sacs extend over the anterior and posterolateral nasofrontal sacs, and the posterior nasal sacs. The muscles are intergraded with dense connective tissue.

The nasal plug muscies are bilaterally paired, and originate from the premaxillae. The 
fibers do not originate from the cartilage of the mesorostral canal. These muscles are ventral to the posterior portion of the melon, and the connective tissue that is anterior to the nasal passage. They are dorsai to the premaxillary sacs and extend anteriorly to the premaxillae. The fibers insert into the connective tissue of the nasal plugs. The muscles are slightly asymmetrical, with the right side somewhat thicker at its posterior aspect.

\section{Melon}

The melon has the typical ovoid structure. Externally, it is covered by a dense dermal connective tissue whose fibers grade into the melon. The melon is composed of connective tissue fibers forming a loose matrix invested with adipose tissue. The core of the melon has fewer connective tissue fibers; it is loose and fatty. The melon does not have the obvious asymmetry that is observed in many delphinid species, nor does it grade into the nasal plugs. Instead, the melon extends posteriorly and terminates several centimeters anterior to the nasal passage. The connective tissue mass that lies anterior tho the nasal passage appears to contain small amounts of adipose tissue.

\section{Phocoenoides dalli}

In many respects the facial anatomy of $P$. dalli is like that of $P$. phocoena. The vestibular, nasofrontal, and posterior nasal sacs are large, while the premaxillary sacs are relatively small. The elliptical bodies, nasal plugs, and diagonal membranes are like their counterparts in P. phocoena. The melon and nasal plugs also are similar.

\section{Nasal Passages}

The blowhole is a crescent shaped opening on the dorsal aspect of the head. It is slightly off of the longitudinal axis, to the left side of the nead. The apices of the blowhole opening are directed anteriorly, with the right side extending a few millimeters further than the left. The anterior lip of the blowhole is composed of dermal connective tissue covered by epidermis, whereas the posterior lip is mainly 
epidermal tissue with a thin connective tissue layer. The blowhole is approximately 3.0 $\mathrm{cm}$ anterior to the vertex.

Most of the nasal sacs are relatively large compared to the sacs of $\mathrm{E}$. phocoena. The vestibular sacs of specimen $\mathrm{MJH} 073$ had a total width of $16.7 \mathrm{~cm}$, a total right length of $9.1 \mathrm{~cm}$, and a total left length of $7.5 \mathrm{~cm}$. Vestibular sacs of specimen RAR $408 \mathrm{had}$ a total width of $15.5 \mathrm{~cm}$, a total right length of $9.1 \mathrm{~cm}$, and a total left length of $7.2 \mathrm{~cm}$.

The entrance to the vestibular sacs is located approximately $3.0 \mathrm{~cm}$ deep to the blowhole where their apertures open to the nasal passage. The sacs extend anterolaterally from the nasal passage, and the anterior tips of the sacs are situated dorsally to the posterior portion of the melon. It is particularly evident that these large vestibular sacs are curved following the edges of the maxillary bone.

The nasofrontal sacs are enclosed in a relatively thick layer of connective tissue and intrinsic muscle (Fig. 16). The nasofrontal sacs of specimens MJH 073 and RAR 408 had total widths of $8.7 \mathrm{~cm}$ and $10.3 \mathrm{~cm}$, respectively. The anterior component of the sacs can be cleanly separated from the fibers of the pars anterointernus which insert ventral

to the sac. There are many nodules on the exterior portion of the sacs, which appear similar to the nodules on the posterior nasal sacs. The posterior nasofrontal sacs and posterior nasal sacs do not differ from the sacs found in $P$. phocoena.

Each posterior septum of the blowhole ligaments has a group of muscle fibers associated with its anterior and ventral surface. The muscle is enclosed within a thin layer of the connective tissue that forms the body of the posterior septum. Thus, the fibers are suspended within the tissue, and in the postmortem state the anterior surface appears less taut than the rest of the structure. The extensions of the posterior septa do not form branches, but flatten out as a part of the dorsal surface of the anterior nasofrontal sacs. There is more tissue of the posterior septa on the right sac than on the left.

Each blowhole ligament has a prominent hyaline cartilage structure at the leading 
margin. These structures are attached by connective tissue fibers to the cartilage of the nasal septum. The cartilaginous pedicle is present posterior to the blowhole ligament and posterior septum. The muscle fibers within the ligament are diffuse.

The premaxillary sacs are small, and the left side also was longer in specimens examined (total right length $1.7 \mathrm{~cm}$, total left length $2.4 \mathrm{~cm}$ for specimen MJH 073; 1.5 and $2.5 \mathrm{~cm}$ for RAR 408). Two of the three specimens had a few trabeculated areas in the lumen of the sacs. On the left side of the adult male specimen there was a small pocket extending less than $1.5 \mathrm{~cm}$ anteriorly.

A secondary fold of epithelium extends from the lateral edge of each side of the bony nares and occupies the floor of the inferior vestibule. This creates a small cranial extension of the inferior vestibule in the form of a "trough" on either side of the nares. This depression was only a three millimeters deep in both adult specimens. At the anterior end of the depression are several trabeculae similar to those that are present in other phocoenid diverticula. The fold of epithelium has the same point of origin as the diagonal membrane. It does not contain muscle fibers, but does have a few connective tissue fibers within its tissue.

\section{Musculature}

Beneath the hypodermis, the band of connective tissue fibers, 5.0 to $7.0 \mathrm{~cm}$ wide, originates from the vertex and a large portion of the nuchal crest. The band extends over the lower part of the vestibular sac, attaches to the supraorbital process, and intergrades with the connective tissue of the melon. These fibers are bound by muscle fascia, to the lateral rostral muscle. The band is generally tendinous near the nuchal crest, and contained muscle tissue in one of the two adult specimens. The most medial fibers fold ventrally and become continuous with the muscle fibers deep to the band. These muscle fibers are oriented perpendicular to the band and do not form a discrete muscle layer. As with $\mathrm{P}$. phocoena, the band of fibers is invested with the adipose tissue that is both above and below it. 
The pars intermedius is deep to the band of fibers and is similar to the same muscle in P. phocoena, with the exception of its origin. In $\mathrm{P}$. dalli, the pars intermedius originates from the supraorbital process, temporal crest, and frontal bone.

Deep to the pars intermedius is the very wide pars anteroexternus. It originates from the maxilla and, anteriorly, from the supraorbital process. The muscle is radially shaped, with fibers inserting around the aperture of the vestibular sac (Fig. 17). The posterior fibers form an aponeurosis with the fibers of the underlying pars posterointernus at their insertion upon the lateral and dorsal aspects of the aperture, whereas anterior fibers insert on the ventral aspect of the sac and aperture. The most anterior fibers, which are a part of the thick fold of muscle as described for P. phocoena, run from the supraorbital process towards the vestibular sac aperture.

Posteromedially, fibers insert on the posterior edge of the nasal passage. The large vestibular sac covers much of this muscle.

Both the pars posterointernus and pars anterointernus originate from the maxilla and are similar to the same muscles in $\mathrm{P}$. phocoena.

The rostral muscles also are like those of $P$. phoceena. Separated by a fine sheet of connective tissue, the muscles form lateral and medial components. Anteriorly there is mostly laieral rostral muscle and dermal connective tissue. Posteriorly, both the lateral and medial rostral muscles are relatively thick. The lateral rostral muscle inserts into the dermal connective tissue of the lips and melon, with a few fibers inserting into the lateral aspect of the melon. A thick portion of the medial rostral muscle spreads out ventral to the melon, and some of these fibers insert onto the sheet of loose connective tissue which is deep to the muscle and dorsal to the mesorostral canal and premaxillae. The remaining fibers of medial rostral muscle radiate dorsally in layers to insert into the melon. At the level of the antorbital notch, the most superficial layer of medial rostral muscle inserts over the dorsal aspect of the melon. 


\section{Size of Nasal Structures}

There appears to be a linear relationship between size of $P$. phocoeris vestibular sacs (see Appendices 1 and 2) and total body length. The trend is particularly evident for total width (TW), total length of the right vestibular sac (TLR), and total length of the left vestibular sac (TLL) (Fig. 18).

This relationship is not demonstrated for all vestibular sac measurements (Table 2). There was no significant relationship between body length of $P$. pheceena and nasofrontal sacs, posterior nasal sacs, or premaxillary sacs. Also, width of nasal plug lips was not dependent on body length in this species (Table 2).

\section{Histology of Phocoenid Nasal Structures}

Tissue sections of the vestibular sacs consisted of a layer of stratified keratinized epithelium over a layer of dense dermal collagen. Dermal papillae were evident and extended at an angle perpendicular to the surface layer.

Samples from the nasofrontal sacs and posterior nasal sacs were composed of a layer of extensively folded stratified squamous epithelium with deep epidermal ridges that overlayed a thick layer of dense collagen. The dermal papillae and collagen layer of the posterior nasofrontal sac were thicker than those of the anterior nasofrontal sac. Some skeletal muscle was observed in the tissue sections. In many foci there was hyperkeratosis and parakeratosis, accompanied by the accumulation of sloughed keratinized cells. Some of the epithelial cell nuclei were vacuolated. No glandular tissue was found in these specimens.

A layer of stratified squamous epithelium was present over a reiatively thin layer of collagen in the premaxillary sacs. The dermal papillae were not as differentiated as those of the other nasal diverticula.

The band of fibers is ccmposed of collagen fibers. In one specimen sectioned for histological observations (EJD 021), the band contained grossly evident muscle tissue. Skeletal muscle fibers were observed in this longitudinal section. 


\section{Nasal Sac Calculi}

Nasal sac calculi were observed in the lumen of the anterior nasofrontal sacs and the posterior nasal sacs of five specimens. The majority of calculi were embedded within the crescentic pores of the epithelial lining, some of these calculi were completely surrounded by a thin tissue layer. There was no evidence of inflammation of the nasal tissue in these areas.

Nasal sac calculi were found in three P. phocoena specimens (NAB 010, NAB 011, LACM 84288). The two nasal calculi found in the anterior nasofrontal sac of NAB 010 measured $1.3 \times 1.1 \times 1.1 \mathrm{~mm}$ and $3.7 \times 2.1 \times 2.1 \mathrm{~mm}$, and collectively weighed $0.08 \mathrm{~g}$. The calculi were light tan, and composed of $80 \%$ calcium carbonate $\left(\mathrm{CaCO}_{3}\right)$ and $20 \%$ apatite $\left[\mathrm{Ca}_{5}\left(\mathrm{PO}_{4}\right)_{3}(\mathrm{OH})\right]$. The larger of the two calculi was irregularly shaped. There were few calculi observed in specimens NAB 011 and LACM 84288, and they had dimensions of $<2.0 \mathrm{~mm}$. Upon gross examination, these calculi appeared to be either yellowish or light tan with generally smooth surfaces.

Eighteen nasal sac calculi were collected from the left and right anterior nasofrontal sacs and right posterior nasal sac of $\mathrm{E}$. dalli (MJH 073), and were $<1.0 \mathrm{~mm}$ to $3.7 \times 3.1$ $\times 2.6 \mathrm{~mm}$ (Fig. 19). Collectively, the calculi weighed $0.05 \mathrm{~g}$. The medium tan to brown surfaces varied from smooth to rough in texture. Cross sections of the calculi revealed surface crystals, a layer of alternating medium tan to lighter tan bands of concentric laminations with a light tan unoriented central core, all composed of $100 \%$ apatite.

The anterior nasofrontal sacs and posterior nasal sacs of specimen RAR 408 ( $P$. dalli; See Figure 26) contained at least 33 calculi, some being so small they could not be counted. These structures were grossly similar to those described above with the exception of six irregularly shaped calculi.

\section{Delphinid Facial Anatomy}

Structure of nasal passages and facial musculature of delphinids is similar to descriptions of Mead (1975); therefore, only a few notable differences will be reported here. Delphinid specimens dissected for comparison are listed in Table 1. 
Several differences were noted for the nasofrontal sacs of some species examined. Lobules were present at the angle of the right nasofrontal sac, and were not present on the left side, in Iusiops truncatus (bottlenose dolphin), Delphinus delphis (common dolphin), Stenella attenuata (pantropical spotted dolphin), and Stenella ceeruleoalba (striped dolphin).

The left and right anterior components of the nasofrontal sacs were present in both specimens of Grampus griseus (Risso's dolphin) examined in this study. In both specimens the right anterior component was three times the diameter of the left, and it extended over $1.0 \mathrm{~cm}$ to the left side of the septum. The blind end of the right anterior component was bifurcate, and in contact with the end of the left anterior component. The left anterior nasofrontal sac was $3.5 \mathrm{~cm}$ long. The accessory sacs were present in both specimens, and in specimen LACA 84268, the left accessory sac connected to a large outpocketing at the angle of the nasofrontal sac.

The lips of the nasal plugs were asymmetrical, with the right side larger than the left in all species examined. The left plug in $\mathrm{D}$ delphis and $\mathbf{S}$.coeruleoalba, however, formed a double lip with a transverse fleshy fold. A small secondary fold of the diagonal membrane was present on the left side in D. delphis species.

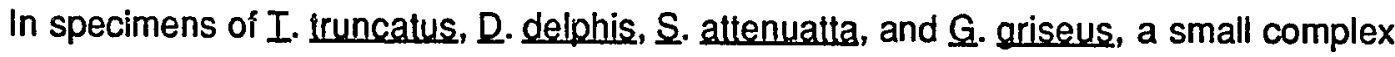
of connective tissue fibers was associated with the anterior portion of the pars pesteroexternus muscle. The fibers did not form a discrete band as in $\mathrm{P}$. phocoena, and inserted into the dermal connective tissue of the melon anterior to the vestibular sac. In one I. truncatus specimen (LACM 84269), there was a well defined band of connective tissue fibers $5.5 \mathrm{cmi}$ wide, which appeared to be more intimately connected with the dermis than in $\mathrm{P}$. phocoena. The band extended from the vertex, passing over the vestibular sac, to the supraorbital process and to the dermal connective tissue of the melon. 


\section{DISCUSSION}

\section{Comparison of Phocoenid and Delphinid Facial Anatomy}

\section{Nasal Passages}

Phocoenid nasal passages and diverticula differ markedly from the homologous structures of delphinids. The upper portion of the spiracular cavity is not very pliable in most delphinids and is directed dorsally as it exits from the bony nares. The vestibular sacs of delphinids lack the deep plica and thick walls of connective tissue of phocoenid vestibular sacs. Instead, these sacs are composed of a thin epithelium and extend lateroposteriorly from the nasal passage.

The nasofrontal sacs of most delphinids are relatively simple structures with anterior and posterior components. The left anterior component was reported as absent in $\mathrm{G}$. griseus (Mead, 1975; Heyning, 1989). However, the left anterior component of the nasofrontal sac was present in both $\mathbf{G}$. griseus specimens examined in the present study. Heyning (personal communication) also found a small, approximately $2.0 \mathrm{~cm}$ long, anterior component to the left nasofrontal sac in a female specimen of G. griseus (LACM 84205). This may be a variable condition for the species. The inferior vestibule opens dorsally into the posterior nasofrontal sac, and the posterior nasal sac is lacking in delphinids (Heyning, 1989).

Mead (1975) did not find any lobulation at the angle of the right nasofrontal sac of $D$. delphis or Stenella spp., but he did observe lobules at the angle of the right sac in I. truncatus. Different degrees of lobulation exist at the angle of the right nasofrontal sac of some delphinids, but the anterior and posterior surfaces are smooth. In phocoenids, the lobulation is at the anterior nasofrontal sacs rather than at the angle of the sacs. Distinct accessory sacs are present in most delphinids. The posterolateral extension of the nasofrontal sacs are the phocoenid homologues of these sacs. The premaxillary sacs ci delphinids are large and extend much further anteriorly than in phocoenids.

Delphinid blowhole ligaments are sirong, fibrous connective tissue structures that extend laterally from just below the vertex to the lateral edge of the premaxillae. Mead (1975) found that occasionally the ligament branched posteriorly, dorsal to the opening 
of the accessory sac, and was attached to the premaxilla posterior to the sac. Heyning (1989) observed that the posterior nasal sac is present in primitive delphinoids, and lost in modern delphinid species.

The blowhole ligament and posterior septum of phocoenids appear as separate branches, or folds, of the sarne structure. The posterior septum separates the posterior nasofrontal sacs from the posterior nasal sacs, and also is present in some ziphiids, monodontids, and platanistids (Heyning, 1989). This condition may sometimes exist, in reduced form, in delphinid specimens. I hypothesize that the blowhole ligament of delphinids may be a derived condition with the secondary loss of the posterior septum which is present in primitive delphinoids.

\section{Musculature}

The muscle patterns of phocoenids and delphinids are generally similar, with only slight differences in origins and insertions. Phocoenids lack the most superficial muscle layer of most delphinidis, the pars pestereexternus. This is true of many delphinid species, and the muscle is particularly variable within the Orcininae (Mead, 1975). Both the pars posteroexternus and pars intermedius are associated with the vestibular sacs of odontocetes. Interestingly, ziphiids lack vestibular sacs and these muscles are lacking in ziphiid species (Heyning, 1989). The pars intermedius is also variable in its presence and degree of development amongst the delphinids.

The pars posteroexternus of delphinids originates along the posterior portion of the supraorbital process, and along the temporal and nuchal crests. It is medially directed and inserts into the connective tissue that is posterior to the blowhole, near the vertex of the skull (Mead, 1975). It is possible that the band of connective tissue fibers that I described for $\mathrm{P}$. phocoena and $\mathrm{P}$. dalli is homologous with the pars pesteroexternus muscle in delphinids.

The most superficial muscle layer of phocoenids corresponds to Gruhl's (1911) description of the pars superficialis and the plan supérieur of Moris (1969). Mead 
(1975) referred to this muscle as "the muscle of the vestibular sac." Gao and Zhou (1988) called this most superficial muscie in $\mathrm{N}$. phocaenoides, the pars posteroexternus. Because of its origin from the temporal and nuchal crests and the anterior direction of fibers inserting into the connective tissue of the melon, I believe this muscle, in $\mathrm{P}$. phocoena and $\mathrm{P}$. dalli at least, is homologous with the pars intermedius of delphinids. Any slight difference in muscle origin probably results from the absence of the pars posteroexternus muscle along the temporal and nuchal crests. In delphinids the pars posteroexternus shares its origin with the pars intermedius. The pars intermedius does not appear to be variable in its presence amongst the phocoenids.

The pars anteroexternus of phocoenids differs from that of delphinids because of its insertion into the paired apertures of the vestibular sacs which are lacking in delphinid species. The pars posterointernus has different insertions for delphinids, but it does form an aponeurosis with the fibers of the pars anteroexternus. The muscle inserts upon the nasofrontal sacs, but there is no posterior nasal sac present in delphinids for insertion. The pars anterointernus muscle is generally similar between the two families.

The nasal plug muscle and the lips of the nasal plugs are larger in delphinids than phocoenids. The delphinid melon is often much more asymmetrical than the melon of phocoenids, and it extends posteriorly into the right nasal plug in most species.

\section{Phocoenid Facial Musculature}

Von Baer (1826) found six layers of facial muscle in $\mathrm{P}$ phoceena, but mentioned that these were variable. Rawitz (1900) separated the muscles into the musculus frontalis and the musculus communis facei. The pars superficialis of Gruhl (1911) included the pars intermedius and the anterior fold of the merged pars anteroexternus and pars anterointernus muscles. Gruhl's pars profundus included the pars anteroexternus, pars posterointerus and pars anterointernus. The muscle layers were separated into two somewhat similar divisions by Moris (1969). The muscle évental plan supérieur includes the pars intermedius and the anterior fold of muscle, the plan moven includes 
the pars anteroexternus and the pars posterointernus, and the plan profond is the pars anterointernus. The muscle layers defined in the present study, after Lawrence and Schevill (1956) and modified by Mead (1975), appear to be of the most functional significance.

\section{Nomenclature of the Blowhole Ligament and Posterior Septum}

There has been some confusion in recent literature regarding the structure which I call the posterior septum of the blowhole ligament. I believe the source of discrepancy is Schenkkan's (1973) treatment of odontocete nasal anatomy in which he stated that Gruhl (1911) referred to the fold of connective tissue (posterior septum) posterior to the blowhole ligament, as both the ethmoturbinale and the hintere Klappe. The following discussion reviews the terminology applied to these structures (Table 3).

Von Baer (1826) described two pairs of Klappen or valves. He referred to the nasal plugs as the Vordere Klappen and mentioned that Cuvier (cited in von Baer, 1826) had previously described the structures. Von Baer also discussed the hintere Klappen (blowhole ligaments) and the structures that he named the aussere Pfeiler and the innere Pfeiler; these are the extensions of a fibrous mass at the nasal septum and the external edge of the nares. Kükenthal (1893) also described the hintere Klappe (blowhole ligament) and referred to the posterior branch of this structure, as the Rudimenten der Ethmoturbinalia as well as several other terms. Kükentîat (1 1833 ) examined fetal specimens, and this observation was made in reference to the soft tissue and cartilaginous elements that are present around the nasal septum (but see de Beer, 1937). Rawitz (1900: Fig 22) was aware of von Baer and Kükenthal's nomenclature, but chose to refer to their hintere Klappe and the Budimenten der Ethmoturbinalia as the frontale Klappe and described two parts, the obere frontale Klappe and the untere frontale Klappe. These are the blowhole igament and the posterior septum. Gruhl (1911) called the transverse fold of tissue (posterior septum) that separates the posterior nasofrontal sac from the posterior nasal sac, the Ethmoturbinale or Ethmoturbinalwülste, and called the blowhole ligament the hintere Klappe. In $\mathrm{P}$. 
phocoena, he treateú titem as structures similar to but "not directly homologous" with the blowincle ligament of delphinids. Gruhl referred to the blowhole ligament of $\mathrm{D}$. delphis and I truncatus, as the hintere Klappe. Thus, hintere Klappe is a term that was originated for the blowhole ligament and is not appropriate when referring only to the posterior septum oi that structure.

In their English language summary, Gao and Zhou (1988) call the lip of the blowhole ligament, the "posterior lip of the nasal passage." They refer to the posterior septum as "the septum between the vomeronasal sac [posterior nasal sac] and the posterior portion of the nasofrontal sac." After evaluating these structures and the above descriptions, 1 believe that the terms blowhole ligament and the posterior septum of the blowhole ligament are best suited to describe them.

\section{Histology of Phocoenid Nasal Structures}

The epithelial lining of phocoenid nasal passages is well suited to the general process of transporting moist, saline air inspired at the air/water interface. The arrangement of well-developed epidermal ridges interdigitating with dermal papillae serves to maintain adhesion between the epidermis and the dermis, and is common to skin that is exposed to significant frictional forces. The dynamic process of keratinization functions to protect the epithelial surface of the skin from dessication and abrasion (Wheater et al., 1985).

The compound acinar exocrine glands found in the crescentic pores of the posterior nasofrontal sacs and inferior vestibule by Maderson (1968) were not evident in any of the samples examined. This could be due to the position of sections or to freshness of sample material in the present study. However, tissue sections were taken at several planes, and the general cell structure of all the samples was good. The composition of the thick fluid observed grossly in the crescentic pores of phocoenid nasal sacs should be analyzed. 


\section{Nasal Sac Calcuii}

There are several major questions regarding the occurrence of biomineralization within the nasal sacs of phocoenids. First, it would be useful to obtain information on the frequency of occurrence of these calculi in a large sample of specimens. Second, even if this is a common occurrence, it may be abnorrnal (pathological) and the effects on the host are unknown. No signs of inflammation were evident upon gross examination of the nasal sacs containing calculi. However, some local irritation could have been present and the accumulation of these calculi within the sacs could obstruct airflow through them. In addition, the mechanism for the biomineralization process should be investigated.

Biomineralization occurs commonly in many organisms (Lowenstam, 1981). In vertebrates, there is normal biomineralization for the formation of skeletal material, and abnormal biomineralization as in urinary and dental calculi. For biomineralization to occur, crystal deposition must take place in a supersaturation of a fluid followed by the nucleation and growth of the mineral within it (Simkiss and Wilbur, 1989). Supersaturation is dependent upon the concentration of precipitating ions, ionic sirength, volume and $\mathrm{pH}$ of the fluid (Smith, 1982). There are known inhibitors of crystal growth in biological fluids and cells, and a decreased concentration of these could permit an abnormal mineralization.

Whether these calculi were produced by primary formation (directly from fluid) or secondary formation (chemical alteration of the formed solid) is interesting because calcium carbonate was in some calculi, whereas in another individual calculi were pure apatite. Sequential mineralization can occur and it is not uncommon for calcium carbonate to be partially or entirely replaced by apatite in response to environmental change (Skinner, 1989).

\section{Phocoenid Sound Production}

Thorough reviews of odontocete sound production were published by Mead (1975), Popper (1980), and Heyning (1989). Most delphinid species produce whistles and 
pulsed sounds, with echolocation clicks that have varying amounts of energy in the ultrasonic region and are short, broadband pulses produced at variable repetition rates (Popper, 1980). Phocoenid species produce narrowband pulses that have the main energy focused at high frequencies (Evans et al., 1988).

Sounds have been recorded for $\mathrm{P}$. phocoena ( Schevill et al., 1969; Dubrovskii et al., 1971; Møhl and Andersen, 1973; Kamminga and Wiersma 1981), P. dalli (Ridgway, 1966; Diercks et al., 1971; Awbrey et al., 1979; Evans et al., 1988), N. phocaenoides (Mizue et al., 1968; Kamminga et al., 1986), and $\mathrm{P}$ sinus (Silber, 1990). Recording equipment used prior to the early 1970's was limited to a narrower bandwidth than the phonations, which led to incomplete analysis (Popper, 1980). Current recording instruments allow measures of frequencies well into the ultrasonic range, and phocoenid species, which were once thought to produce only very low frequency sounds are now known to use very high frequency clicks. P. phocoena has a peak frequency of $128 \mathrm{kHz}$ with a narrow band width, and a pulse duration of $100 \mu$ s (Møhl and Andersen, 1973). P. dalli produces sounds of a narrow band spectrum with a peak frequency level of 134 $\mathrm{k} h \dot{\mathrm{n}} \mathrm{z}$ and single pulses lasting approximately $500 \mu \mathrm{s}$, with double pulses lasting approximately half this time (Evans et al., 1988).

Silber (1990) has suggested that the interspecific similarity of phocoenid sounds may be related to habitat use, and indicated that the habitats include complicated acoustic environments. Phocoenids inhabit generally nearshore, shallow, and often murky waters. A delphinid genus known to produce similar high frequency sounds, the Cephalorhynchus spp. (Watkins et al., 1977), also inhabits nearshore and turbid water areas, and the similarity may be related to this ecological factor.

Anatomical comparisons between the phocoenids and Cephalorhynchus commersonii (commerson's dolphin) have also been made to investigate possible similarities that might function in the production of high frequency signals. The facial anatomy of $P$. phocoena and S. commersonii was compared using a method of serial sectioning combined with computer-generated stereograms (Amundin et al., 1988; Amundin and Cranford, 1990). No striking similarities were found between the two distantly related 
species; several differences, however, were noted, and the similar size and shape of the anterior nasofrontal sacs were described. Heyning (1989) noted several potentially important features that are similar between these two grcups. The posterior end of the melon does not extend into either nasal plug, and both groups have large nasal diverticula, the vestibular sacs, that are situated dorsal to the posterior tip of the melon. Schenkkan (1973) found the blowhole ligaments were positioned similarly to those of ziphiid species.

Phocoenids are not known to produce whistles (Mizue et al., 1968; Schevill et al.,1969; Herman and Tavolga, 1980; Silber, 1990). Whistles also appear to be absent for iniids, platanistids, and Cephalorhynchus spp. and the question of whether anatomical or ecological factors might cause this difference is intriguing (Evans and Awbrey, 1988). Silber (1990) discussed the probable social and behavioral functions of whistles and their possible importance to pelagic species that form large schools. He suggested the lack of whistles among some species may be attributed to ecological factors, such as similarity of habitat, and small group size.

\section{Function of Phocoenid Facial Structures}

\section{Nasal Passages}

Many investigations support the suggestion of Norris (1964) that the vestibular sacs of delphinids function as reservoirs for air that can be recycled into the nasal system (Norris et al., 1971; Dormer, 1979; Ridgway et al., 1980). The highly distensible vestibular sacs of $P$. phocoena and $P$. dalli are well suited for this purpose. The muscle control of the vestibular sac apertures (pars anteroexternus), allows them to be opened to inflowing air. The unique configuration of plica at the apertures to the vestibular sacs could create a pneumatic lock, maintaining inflation until air is required elsewhere in the nasal passage. The plica may also serve to control pressure by directing airflow into the passage.

The vestibular sacs also were proposed to act as reflecting surfaces for sounds which have been produced within the nasal passage (Norris, 1964). The large vestibular sacs 
of phocoenids, with their complex configuration covering much of the nasal passage and extending over the posterior end of the melon, are capable of changing shape and thus could affect the sound field (Mead, 1975).

The nasofrontal sacs open to the nasal passages at the angle of the sacs and through the posterolateral extension. Amundin and Andersen (1983) proposed that the nasofrontal sacs of $P$. phocoena can inflate to seal the nasal passage. This function was suggested for delphinid nasofrontal sacs (Lawrence and Schevill, 1956). The morphology of phocoenid nasofrontal sacs and the possible mechanisms for closure (see below) do not appear to facilitate this type of pneumatic seal. Heyning and Mead (1990) discussed the absence of the anterior component in several ziphiids and iniids, and the absence of the left anterior component in $\mathbf{G}$. griseus (although this structure has since been found in $\mathbf{G}$. griseus specimens). They suggested that if the nasofrontal sacs had such a significant role as providing a watertight seal, the entire structure would be present in all species.

The nasofrontal sacs are located near the elliptical bodies, nasal plug lips and the blowhole ligament, and may have a role in sound production. The nasofrontal sacs and the posterior nasal sacs, with their porous tissue, appear to have a secretory function. The nasofrontal sacs may function as resonators; Ridgway et al. (1980) proposed that secretions might function as damping elements that allow fine control of frequency.

The premaxillary sacs of phocoenids appear to enlarge the air space of the posterior nasal sacs and inferior vestibule if the space is not occluded by the posterior septum. An incidental function of the premaxillary sac in odontocetes may be to allow freer movement of the overlying nasal plug muscle (Heyning and Mead, 1990).

The position of the posterior septum (referred to as the hintere Klappe) within the facial region of $\mathrm{P}$. phocoena has been demonstrated recently with the use of three dimensional computer reconstruction (Amundin et al., 1988). The posterior septum may act as a valve to occlude the inferior vestibule and posterior nasal sacs, and function to control airflow through the passages. Tension from the pars pesterointernus could pull the posterior septum ventrally, thus occluding the inferior vestibule with the ventral portion of the structure resting on the floor of the vestibule. In $\mathrm{D}$. dalli, the 
presence of muscle fibers within the posterior septum suggests that it is capable of some independent movement. The branches of the posterior septum in $\mathrm{P}$. phocoena, and the flattened extensions of the structures in $\mathrm{P}$. salli, could respond to muscle tension by pulling posteroventrally on the anterior nasofrontal sacs, which might close the openings of these sacs.

The posterior septum and blowhole ligament arise from the same location on the cranium and are in close proximity to each other. The blowhole ligament with its relatively thick muscular lip and association with the pars pesterointernus muscle, may close the cavity ventral to the posterior nasofrontal sac by pressing against the posterior septum. The blowhole ligament, in combination with the posterior septum, may also occlude the inferior vestibule and posterior nasal sacs.

The lips of the blowhole ligaments are juxtaposed to the lips of the nasal plugs. These two structures are capable of movement against one another. Evans (1973) proposed that the nasal plugs are used in odontocete sound production by means of "relaxation oscillations" created by movement against the bony nares. Delphinid echolocation clicks are produced at the general region of the right nasal plug, and whistles (absent in phocoenids) are produced at that of the left plug (Norris et al., 1971; Dormer, 1979).

Heyning (1989) suggested that the blowhole ligaments of ziphiids may function in sound production by vibrating against the nasal plugs when air is forced past them. He noted that sound could then be transmitted through the elliptical bodies to the melon (see Cranford, 1988). The elliptical bodies of ziphiids and phocoenids are located at the same points, but are described only for the right side of the head in ziphiids (Heynirig, 1989). Although there appear to be distinct differences between the blowhole ligament of ziphiids and phocoenids, similarities are present. The cartilaginous elements described for the blowhole ligament in species of Mesoplodon (Heyning, 1989:Fig. 19) appear to be similar to those found in this study in $\mathrm{P}$. phocoena and $\mathrm{P}$. dalli.

The nasal passages of $P$. pheceena and $P$. dalli are well suited for complex air movement past the nasal plugs and blowhole ligaments. These paired structures are capable of 
either independent movement, or movement as the result of muscie tension. The lips of the blowhole ligaments and nasal plugs are able to move against the small diagonal membranes and bony nares. Ridgway et al. (1980) demonstrated that the diagonal membrane muscles are active during sound production in I. truncatus. The lips of the blowhole ligaments are capable of complex movement, and may cause the cartilage and ligaments to vibrate against the nasal plugs. This action may function in the sound production of phocoenids. The question of sound transmission to the melon is more difficult. The elliptical bodies are not continuous with the melon in phocoenids. I agree with Heyning (1989) that caution must be used in evaluating a hypothesis that is based on anatomical evidence alone.

\section{Size of Nasal Structures}

The relationship between increasing size of the vestibular sacs and total body length in P. phecoena may demonstrate the requirement for an air sac size that is proportional to body size. If the vestibular sacs act as a reflective surface for sounds produced in the nasal passage, as suggested by Norris (1964), size of sacs relative to body (head) size, could be important for the effectiveness of the reflector. The size of the vestibular sacs in relation to body size also may be important if the sacs function for air recycling as suggested by Norris (1964). A larger individual might require greater amounts of air for sound production and transmission to the environment.

The vestibular sacs appear to reach a particular size by the time a young individual must be independent of adult care (Figure 23). In his study of Stenella attenuatta (pantropical spotted dolphin) and Stenella longirostris (spinner dolphin), Perrin (1975) found that there is precocious development of cranial elements associated with the breathing and sound-producing apparatus. Yurick and Gaskin (1988) quantitatively examined asymmetry of the $\mathrm{P}$. phocoena skull and concluded that the skew (degree of sinistrad asymmetry) was not correlated with skull length, but that certain cranial elements associated with sound production must obtain a skew of adult proportions at a young age. 
The nasofrontal, posterior nasal, and premaxillary sacs of $\mathrm{P}$. phoceena do not appear to be as well suited to sound reflection and air storage. However, if the nasofrontal sacs have a secretory function or function in some other manner within the nasal passage, their size would not necessarily be dependent on body size.

The nasal plug width was not dependent on body length. Instead, the lips of the nasal plugs may have a relationship with the width of the spiracular cavity which showed only a slight dependency on total body length.

The number of samples for all of the simple linear regressions tested was small, but results shown in figure 18 were significant $(p<0.01)$. A measurement of the sac volume also may have been useful for determining the relationship between size of nasal sacs and total body length.

\section{Musculature}

The band of connective tissue fibers I described for $\mathrm{P}$. phocoena and $\mathrm{P}$. Dalli has not been described in other odontocete species. It appears to be a subdermal structure sharing some of the mechanical properties assigned to the subdermal connective tissue sheath of cetaceans (Pabst, 1990). The band serves as a point of insertion for the lateral rostral muscle, which can pull the band craniad. This movement could cause some minimal compression of the vestibular sac. In specimens with bands containing muscle fibers, the structure is potentially capable of isolated movement. The band of fibers also serves to separate the underlying musculature from the blubber layer.

The pars intermedius may function to compress the vestibular sac and, as evidenced by the distinct tendinous area at the posterior aspect of the sac, to pull it caudad. The muscle can retract the lateral lip of the blowhole, and probably functions with other muscle layers to create tension on the melon. In most delphinids, the pars intermedius does not appear to have an important function, and the pars posteroexternus is considered to function as a compressor of the vestibular sac while restricting vertical expansion of the sac (Mead, 1975; Green et al., 1980).

The pars anteroexternus is likely to have the primary function of controlling the 
aperture of the vestibular sac. Fibers inserting on the dorsal aspect of the aperture may retract to pull the sac caudad towards the nasal passage. The anterior fibers act antagonistically on the ventral aspect of the aperture and the anterior wall of the nasal passage, pulling them forward. The posteromedial fibers of the pars anteroexternus can pull the posterior lip of the blowhole caudad. In delphinids, which do not possess a distinct aperture of the vestibular sacs, the pars anteroexternus functions as a dilator of the nasal passage (Mead, 1975).

The thick fold of the pars anteroexternus and pars anterointernus maintains tension on the vestibular sac, keeping it in position, and may also force air from the sac while pulling it laterally and slightly craniad. These functions have been suggested for the pars anteroexternus of I. truncatus (Lawrence and Schevill, 1956; Green et al., 1980).

The pars posterointernus pulls the wall of the nasal passage posteriorly and laterally. The fibers inserting at the posterior elliptical bodies appear to have excellent control of their movement. The muscle can cause tension on the posterior nasal sac and the lateral aspect of the nasofrontal sac. It also has some control of the posterior septum and the blowhole ligament. The pars pesterointernus is active during sound production in $I$. truncatus (Ridgway et al., 1980)

Mead (1975) and Green et al. (1980) consider the pars posterointernus of delphinids to function in pulling the posterior wall of the spiracular cavity forward. The muscle inserts slightly more anteriorly on the supraorbital process in delphinids than in phocoenids, and more fibers are directed posteriorly from this origin, which would suggest such movement. This difference could be due to general size differences between the two families, in addition to differences in cranial features. In delphinids, the pars posteroexternus may assist in moving the blowhole ligament craniad to the nasal plug lip (Mead, 1975; Green et al., 1980). In P. phocoena and $\mathrm{P}$. dalli, the pars posterointernus appears to pull ventrad and only slightly anteriad upon the blowhole ligament. The lip of the blowhole ligament has its own intrinsic muscle in these two species, which may manipulate the lip of the structure either towards the nasal plug lip or to the floor of the inferior vestibule. 
The pars anterointernus functions to pull the nasal plugs ventrad and caudad towards the blowhole ligament, and to draw the anterior wall of the nasal passage caudad. This action can effectively close the nasai passage. This action can also compress the premaxillary sacs. The same functions are attributed to the pars anterointernus of delphinids (Lawrence and Schevill, 1956; Purves, 1967; Mead, 1975; Green et al., 1980). This muscle contracts during sound production in I. truncatus (Ridgway et al., $1980)$.

The vestibular sac intrinsic muscle probably helps maintain contact of the two sacs at their medial aspects. The vestibular sac intrinsic muscle may also aid in the fine control of the sac's movements (Mead, 1975).

\section{Melon}

The odontocete melon is composed of nonhomogeneous lipids that may serve to control the shape of the sound field through refraction, interference, and differential velocity of sound pulses which are then transmitted to the water (Norris, 1964; Litchfield et al., 1973; Norris and Harvey, 1974). Cranford (1988) referred to the elliptical bodies as the dorsal bursae and demonstrated, with $X$-ray computed tomography, that in many species these structures are functionally continuous with the melon tissue. He suggested that the structures may be involved in the generation and transmission of sounds to the melon.

If this hypothesis is valid, some additional mechanism for sound transmission in phocoenids (and Cephalorhynchus spp.) also may be present considering the discontinuity of the melon and elliptical bodies. The mesorostral cartilage may carry high frequency sounds in delphinids and phocoenids (Purves, 1967; Diercks et al., 1971; Evans 1973; Norris, 1980). The complex cartilaginous structures associated with the blowhole ligament of $P$. phocoena and $P$. dalli are continuous with the cartilage of the mesorostrai canal. Also, the premaxillary sacs are dorsal to the posterior end of the canal and could serve as a reflecting surface. As described earlier for $\mathrm{P}$. phocoena, the mesorostral cartilage is covered only by' a thin layer of loose connective tissue. 
Partial energy of sound waves in this cartilage could theoretically be taken up by the melon and focused for transmission to the environment. It should be noted here that mysticetes also have a mesorostral cartilage, but probably do not produce sounds in the same way as odontocetes.

The nasal passages, diverticula, and associated structures of $\mathrm{P}$. phocoena and $\mathrm{P}$. dalli are complex compared with those of most delphinid species. The vestibular sacs and anterior nasofrontal sacs of phocoenids are hypertrophied, posterior nasofrontal sacs are compressed; and the premaxillary sacs are relatively small. There are paired posterior sacs, the posterior nasal sacs, present above the inferior vestibules. The blowhole ligament of phocoenids is structurally divided into two branches. The posterior branch, which I call the posterior septum of the blowhole ligament in the present study, was described as the Budimenten der Ethmeturbinalia by Kükenthal (1893). In most delphinids, the blowhole ligament represents the derived condition with the loss of the posterior septum of the blowhole ligament.

There is a well defined band of connective tissue fibers present on the lateral aspect of the head at the subdermal level. This band may be homologous to the pars pesteroexiernus of delphinids. The facial musculature is similar to the muscles of delphinids, and the pars posteroexternus muscle is absent. There is also a vestibular sac intrinsic muscle surrounding the sac.

I have presented several suggestions for the functions of phocoenid facial structures. The insertion of the pars anteroexternus around the apertures of the vestibular sac may allow its movement over the nasal passage for airflow. The anterior nasofrontal sacs and posterior nasal sacs appear to have a secretory function, although no glands were found. The lips of the blowhole ligaments may be involved with the nasal plug lips in phocoenid sound production, but this suggestion does not preclude the concept that other facial structures may function in sound production. In phocoenids, it appears that the mesorostral canal may transmit high frequency sounds from the nasal passages to the melon. The anatomical evidence demonstrates that sound production in phocoenids results from the integration of a system of highly complex facial structures and muscle movement. 


\section{ACKNOWLEDGMENTS}

I thank the peopie of Moss Landing Marine Laboratories and the Long Marine Laboratory who, through their generosity, showed me that research is the result of the collaboration and efforts of many people. Nancy A. Black, Eric J. Dorfman, Ronnie Estelle, Charles Haugen, James T. Harvey, John E. Heyning, Thomas A. Jefferson, Linda L. Jones, Robert E. Jones, Thomas R. Kieckhefer, Raymond J. Tarpley, and Graham A. J. Worthy provided specimens for this study. Tony Bennett, Susan L. Kruse, and Thomas E. Lewis participated in several dissections. Patricia Day assisted in the analysis of histological samples. Evelyn Hanggi, Thomas Henningsen and Guillermo Moreno translated publications. Sheila and Alan Baldridge supplied literature and an open network of marine mammal stranding information. Sam H. Ridgway was particularly generous with his time and knowledge, especially with the serial sectioning of specimens. I appreciate the guidance of Randall S. Wells, and thank James G. Mead for several dissections and discussions on the subject of odontocete facial anatomy. I thank my major advisor Bernd Würsig for providing guidance and equipment for this study. Gregor M. Cailliet, James T. Harvey, John E. Heyning, and Kenneth S. Norris also served on my thesis committee and they too contributed their knowledge and experience to this thesis. I thank Thomas A. Jefferson for his comments on this manuscript, and for his assistance in innumerable other aspects of my research. 


\section{LITERATURE CITED}

AMUNDIN, M., and ANDERSEN, S. H. 1983. Bony nares air pressure and nasal plug muscle activity during click production in the harbour porpoise, Phocoena phocoena, and the bottlenose dolphin, Iursiops truncatus. J. Exp. Biol., 105: 275-282.

AMUNDIN, M., and CRANFORD, T. 1990. Forehead anatomy of Phocoena phocoena and Cephalerhynchus commersonii: 3-dimensional computer reconstructions with emphasis on the nasal diverticula. In Sensory Abilities of Cetaceans: Laboratory and Field Evidence. Edited by J. A. Thomas and R. A. Kastelein. Plenum Press, New Yo:k. pp. 1-18.

AMUNDIN, M., KALLIN, E., and KALLIN, S. 1988. The study of the sound production apparatus in the harbour porpoise, Pheceena phocoena, and the jacobita, Cephalorhynchus commersoni by means of serial cryo-microtome sectioning and 3D computer graphics. In Animal Sonar: Processes and Performance. Edited by P. E. Nachtigall and P. W. B. Moore. Plenum Press, New York. pp. 61-66.

AWBREY, F. T., NORRIS, J. C., HUBBARD, A. B., and EVANS, W. E. 1979. The bioacoustics of the Dall porpoise-salmon drift net interaction. Hubbs/Sea World Research Institute Technical Report 79-120. Available from Hubbs Marine Research Institute, 1700 South Shores Road, San Diego, CA, 92109, USA.

BARNES, L. G. 1985. Evolution, taxonomy and antitropical distributions of the porpoises (Phocoenidae, Mammalia). Mar. Mamm. Sci. 1: 149-165.

BARNES, L. G., DOMNING, D. P., and RAY, C. E. 1985. Status of studies on fossil marine mammals. Mar. Mamm. Sci. 1: 15-53.

BARNES, L.G., and MITCHELL, E. 1978. Cetacea. In Evolution of African Mammals. Edited by V. J. Maglio and H. B. S. Cooke. Harvard University Press, Cambridge. pp 582-602.

CHRISTENSEN, I. 1984. Growth and reproduction of killer whales, Orcinus orca, in Norwegian coastal waters. Rep. Int. Whaling Commn. Special Issue 6: 253-258. 
CRANFORD, T. W. 1988. The anatomy of acoustic structures in the spinner dolphin forehead as shown by $X$-ray Computed Tomography and computer graphics. In Animal Sonar: Processes and Performance. Edited by P. E. Nachtigall and P. W. B. Moore. Plenum Press, New York. pp. 67-77.

dE BEER, G. R. 1937. The Development of The Vertebrate Skull. University of Chicago Press, Chicago. pp. 345-346, 394-397.

DIERCKS, J. J., TROCHTA, R. T., GREENLAW, R. L., and EVANS, W. E. 1971. Recording and analysis of dolphin echolocation signals. J. Acoust. Soc. Am. 49: 1729-1732.

DORMER, K. J. 1979. Mechanism of scund production and air recycling in delphinids: Cineradiographic evidence. J. Acoust. Soc. Am. 65: 229-239.

DUBROVSKII, N. A., KRASNOV, P. S., and TITOV, A. A. 1971. On the emission of echolocation-signals by the Azov Sea harbour porpoise. Sov. Phys.-Acoust.

16: $444-448$.

EDGEWORTH, F. H. 1935. The Cranial Muscle of Vertebrates. University Press, London.

EVANS, W. E. 1973. Echolocation by marine delphinids and one species of fresh-water dolphin. J. Acoust. Soc. Am. 54: 191-199.

1975. Distribution, differentiation of populations, and other aspects of the natural history of Delphinus delphis Linnaeus in the northeastern Pacific. Ph.D. Disseriation, Univ. of Caiif., Los Angeles, California.

EVANS, W. E., and PRESCOTT, J. H. 1962. Observations of the sound capabilities of the bottlenose porpoise: A study of whistles and clicks. Zoologica, 47:121-126.

EVANS , W. E., and AWBREY, F. T. 1988. Natural history aspects of marine mammal echolocation: Feeding strategies and habitat. In Animal Sonar: Processes and Performance. Edited by P. E. Nachtigall and P. W. B. Moore. Plenum Press, New York. pp. 521-534.

EVANS, W. E., AWBREY, F. T., and HACKBARTH, H. 1988. High frequency pulses produced produced by free-ranging Commerson's dolphins (Cephalorhynchus 
commersonii) compared to those of phocoenids. Rep. Int. Whaling Commn. Special Issue 9: 173-181.

FRASER, F. C., and PURVES, P. E. 1960. Hearing in cetaceans. Evolution of the accessory air sacs and the structure and function of the outer and middle ear in recent cetaceans. Bull. Brit. Mus. (Natural History), Zool. 7: 1-140.

GALLARDO, A. 1913. Notas sobre la anatomia del aparato espiracular, laringe y hiodes de dos delfines: Phocaena dioptrica Lahille y Lagenorhynchus fitzroyi (Waterhouse) Flower. Annals de Museo Nacional de Historia Natural de Buenos Aires (Museo Argentino de Ciencias Naturales). 24: 235-245.

GAO, G. and ZHOU, K. 1988. Studies on the anatomy and architecture of the nasai tract muscles of the finless porpoise, Neophocaena phocaenoides. Acta Theriol. Sin. 8: $261-270$. 1989 Anatomy of the nasal passage and associated structures of Neophocaena phocaenoides. Acta. Theriol. Sin. 9: 275-280.

GREEN, R. F., RIDGWAY, S. H., and EVANS, W. E. 1980. Functional and descriptive anatomy of the bottlenosed dolphin nasolaryngeal system with special reference to the musculature associated with sound production. In Animal Sonar Systems. Edited by R.-G. Busnel and J. F. Fish. Plenum Press, New York. pp. 199-238.

GRUHL, K. 1911. Beiträge zur anatomie und physiologie der cetaceennase. Jen. Zeitschr. Naturw. 47: 367-414.

HERMAN, L. M., and W. N. TAVOLGA. 1980. The commuinication systems of cetaceans. In Cetacean Behavior. Edited by L. M. Herman. John Wiley and Sons, New York. pp.149-209.

HEYNINGG, J. E. 1989. Comparative facial anatomy of beaked whales (Ziphiidae) and a systematic revision among the families of extant Odontoceti. Contr. Sci., Nat. Hist. Mus. Los Angeies Co. 405: 1-64.

HEYNING, J. E., and MEAD, J. G. 1990. Evolution of the nasal anatomy of cetaceans. In Sensory Abilities of Cetaceans: Laboratory and Field Evidence. Edited by J. A. 
Thomas and R. A. Kastelein. Plenum Press, New York. pp. 67-79.

HOHN, A. A., and R. L. BROWNELL, JR. 1990. Harbor porpoise in central California waters: Life history and incidental catches. IWC Scientific Committee Report, SC/42/SM47. Available from The International Whaling Commission, The Red House, Station Road, Histon, Cambridge, CB4 2NP, UK.

HOWELL, A. B. 1927. Contribution to the anatomy of the Chinese finless porpoise, Neomeris phocaenoides . Proc. U.S. Natl. Mus. 70: 1-43.

HUBER, E. 1934. Anatomical notes on Pinnipedia and Cetacea. In: Marine Mammals, Contributions to Paleontology. Edited by E. L. Packard, R. Kellogg and E. Huber. Washington, D.C.: Carnegie Institution of Washington pp. 107-136.

JONES, L. L., BOUCHET, G. C., and TURNOCK, B. J. 1987. Comprehensive report on the incidental take, biology, and status of Dall's porpoise. Document submitted to the Ad Hoc Committee on Marine Mammals, International North Pacific Fisheries Commission. Available from National Marine Mammal Laboratory, NOAA, 7600 Sand Point Way N. E., Seattle, WA, 98115, USA.

KAMMINGA, C., KATAOKA, T., and ENGELSMA, F. J. 1986. Investigations on cetacean sonar VII. Underwater sounds of Neophocaena phocaenoides of the Japanese coastal population. Aquat. Mamm. 12: 52-60.

KAMMINGA, C., and WIERSMA, H. 1981. Investigations on cetacean sonar II. Acoustical similarities and differences in odontocete sonar signals. Aquat. Mamm. 8: 41-62. KASUYA, T., and IZUMISAWA, Y. 1985. Fishery-dolphin conflict in the Iki Island area of Japan. In Marine Mammals and Fisheries. Edited by J. R. Beddington, R. J. H. Beverton, and D. M. Lavigne. George Allen \& Unwin, London. pp. 253-272.

KüKENTHAL, W. 1893. Vergleichend-anatomische und Entiwickelungsgeschichtliche Untersuchungen an Walthieren. Denkschr. Med. Naturw. Ges. zu Jena. 3:1-448. LAWRENCE, B., and SCHEVILI, W. E 1956. The functional anatomy of the delphinid nose. Bull. Mus. Comp. Zool. 114: 103-151. 
1965. Gular musculature in delphinids. Bull. Muss. Comp. Zool. 133: 1-

65.

LILLY, J .C., and MILLER, A. M. 1961. Sounds emitted by the bottlenose dolphin. Scierice, 133: 1689-1693.

LITCHFIELD, C., KAROL, R., and GREENBERG, A. J. 1973. Compositional topography of melon lipids in the Allantic boltlenose dolphin Iursiops truncatus : Implications for echolocation. Mar. Biol. 23: 165-169.

LOWENSTAM, H. A. 1981. Mineral formed by organisms. Science 211: 1126-

1131.SIMKISS, K., and WILBUR, K. M. 1989. Biomineralization, Cell Biology and Mineral Deposition. Academic Press, San Diego. pp 11-20.

MADERSON, P. F. 1968. The histology of the nasal epithelia of Tursiops truncatus (Cetacea) with preliminary observations on a series of glandular structures. Am. Zool. 8: 810 (abstract).

MEAD, J. G. 1975. Anatomy of the external nasal passages and facial complex in the Delphinidae (Mammalia: Cetacea). Smithsonian Contr. Zool. 207: 1-72.

MIZUE, K., TAKEMURA, A., and NAKASAI, K. 1968. Underwater sounds of the Chinese finless porpoise caught in the Japanese coastal sea. Bull. Faculty of Fisheries, Nagasaki University. 25: 25-33.

MILLER, G. S., Jr. 1923. The telescoping of the cetacean skull. Smithsonian Misc. Coii. $76: i-7 i$.

MøHL, B. and ANDERSEN, S. 1973. Echolocation: High frequency component in the click of the harbor porpoise (Phocoena phoceena L.). J. Acoust. Soc. Am. 54: 368372.

MORIS, F. 1969. Étude anatomique de la région cephalique du marsouin, Phocaena phocaena L. (cétacé odontocète). Mammalia, 33: 666-726.

MURIE, J. 1870. On Risso's Grampus, G. rissoanus (Desm.). J. Anat. Phys. 5: 118-138.

NORRIS, K. S. 1964. Some problems of echolocation in cetaceans. In Marine BioAcoustics. Edited by W.N. Tavolga. Pergamon Press, Oxford. pp. 317-336. 
- 1980. Peripheral sound processing in odontocetes. In Animal Sonar

Systems. Edited by R.-G. Busnel and J.F. Fish. Plenum Press, New York. pp. 495509.

NORRIS, K. S., DORMER, K. J., PEGG, J., and LIESE, G. J. 1971. The mechanism of sound production and air recycling in porpoises: A preliminary report. In Proceedings of the Eighth Annual Conference on Biological Sonar and Diving Mammals, Menlo Park, CA, October 22-23, 1971. Edited by T. C. Poulter. Stanford Research Institute, Menlo Park, CA. pp. 113-129.

NORRIS, K. S., and HARVEY, G. W. 1974. Sound transmission in the porpoise head. J. Acoust. Soc. Am. 56: 659-664.

PABST, D. A. 1990. Axial muscles and connective tissues of the bottlenose dolphin. In The Bottlenose Dolphin. Edited by S. Leatherwood and R. R. Reeves. Academic Press, San Diego. pp. 51-67.

PERRIN, W. F. 1975. Variation of spotted and spinner porpoise (genus Stenella) in the eastern tropical Pacific and Hawaii. Bull. Scripps Inst. Oceanogr. 21: 1-206. 1989. Dolphins, Porpoises, and Whales, an Action Plan for the Conservation of Biological Diversity: 1988-1992. Int. Union Cons. Nat., Switzerland.

PERRIN, W. F., COE, J. M., and ZWEIFEL, J. R. 1976. Growth and reproduction of the spotted porpoise, Stenella attenuata, in the offshore eastern tropical Pacific. Fish Bull. 74: 229-269

POPPER, A. N. 1980. Sound emission and detection by delphinids. In Cetacean Behavior: Mechanisms and Functions. Edited by L. M. Herman. John Wiley and Sons, New York. pp. 1-52. .

PURVES, P. E. 1967. Anatomical and experimental observations on the cetacean sonar system. In Animal Sonar Systems: Biology and Bionics. Volume I. Edited by R.-G. Busnel. pp.197-270. Imprimerie Louis Jean, GAP (Hautes-Alpes).

RAWITZ, B. 1900. Die anatomie des Kehlkopfes und der nase von Phocoena communis Cuv. Int. Monatschr. Anat. Physiol. 17: 245-354. 
REIDENBERG, J.S., and LAITMAN, J.T. 1988. Existence of vocal folds in the larynx of Odontoceti (toothed whales). Anat. Rec. 221: 884-891.

RIDGWAY, S. H. 1966. Dall porpoise, Phocoenoides dalli (True): Observations in captivity and at sea. Norsk Hval.-Tid. 55: 97-110.

RIDGWAY, S. H., and CARDER, D. A. 1988. Nasal pressure and sound production in an echolocating white whale, Delphinapterus leucas. In Animal Sonar: Processes and Performance. Edited by P. E. Nachtigall and P. W. B. Moore. P!enum Press, New York. pp. 53-60.

RIDGWAY, S. H., CARDER, D. A., GREEN, R. F., GRANT, A. S. , GRANT, S. L. L., and EVANS, W. E. 1980. Electromyographic and pressure events in the nasolaryngeal system of dolphins during sound production. In Animal Sonar Systems. Edited by R.-G. Busnel and J. F. Fish. Plenum Press, New York. pp.239-249.

SCHENKKAN, E. J. 1973. On the comparative anatomy and function of the nasal tract in odontocetes (Mammalia, Cetacea). Bijdragen tot de Diekunde. 43:127-159.

SCHEVILL, W. E., WATKINS, W. A. and RAY, C. 1969. Click structure in the porpoise Phocoena phocoena. J. Mammal. 50: 721-728.

SERGEANT, D. E., CALDWELL, D. K., and CALDWELL, M. C. 1973. Age, growth, and maturity of bottlenosed dolphin (Tursiops truncatus) from northeast Florida. J. Fish. Res. Bd Can. 30: 1009-1111.

SIBSON, F. 1848. On the blow-hole of the porpoise. Phil. Trans. Roy. Soc. Lond. 1848: $117-123$.

SILBER, G. K. 1990. Distributional relations of cetaceans in the northern Gulf of California, with special reference to the vaquita, Phocoena sinus. Ph.D. Dissertation, Univ. of Calif., Santa Cruz, California.

SKINNER, H. C. W. 1989. Low temperature carbonate phosphate materials or the carbonate-apatite problem: A review. In Origin, Evolution, and Modern Aspects of Biomineralization in Plants and Animals. Edited by R. E. Crick. Plenum press, New york. pp. 251-264. 
SMITH, L.H.1982. Abnormal mineralization. In Biological Mineralization and Demineralization. Edited by G. H. Nancollas. Springer-Verlag, New York. pp 259270.

VON BAER, K. E. 1826. Die Nase der Cetacean erlautert durch untersuchung der nase des braunfisches (Delphinus phocaena). Isis von Oken, 19: 811-847.

VON BOAS, J. E. and PAULLI, S. 1908. The Elephant's Head: Studies in the Comparative Anatomy of the Organs of the Head of the Indian Elephant and Oiher Mammals, Part I: The Facial Muscles and the Proboscis. Gustav Fischer, Jena. 38 pp.

WALKER, W. A. 1981. Geographical variation in morphology and biology of bottlenose dolphins (Tursiops) in the eastern North Pacific. SW.F.C. Admin. Rep. LJ-81-03C. Available from Southwest Fisheries Science Center, PO Box 271, La Jolla, CA, 92038, USA.

WATKINS, W. A., SCHEVILL, W. E. and BEST. P. B. 1977. Underwater sounds of Cephalorhynchus heavisidii (Mammalia: Cetacea). I. Mammal. 58: 316-320. WHEATER, P. R., H, G. BURKITT, and V. G. DANIELS. 1985. Functional Histology. Churchill Livingstone, New York.

YURICK, D. B., and GASKIN, D. E. 1988. Asymmetry in the skull of the harbour porpoise Phocoena phocoena (L.) and its relationship to sound production and echolocation. Can. J. Zool. 66: 399-402. 


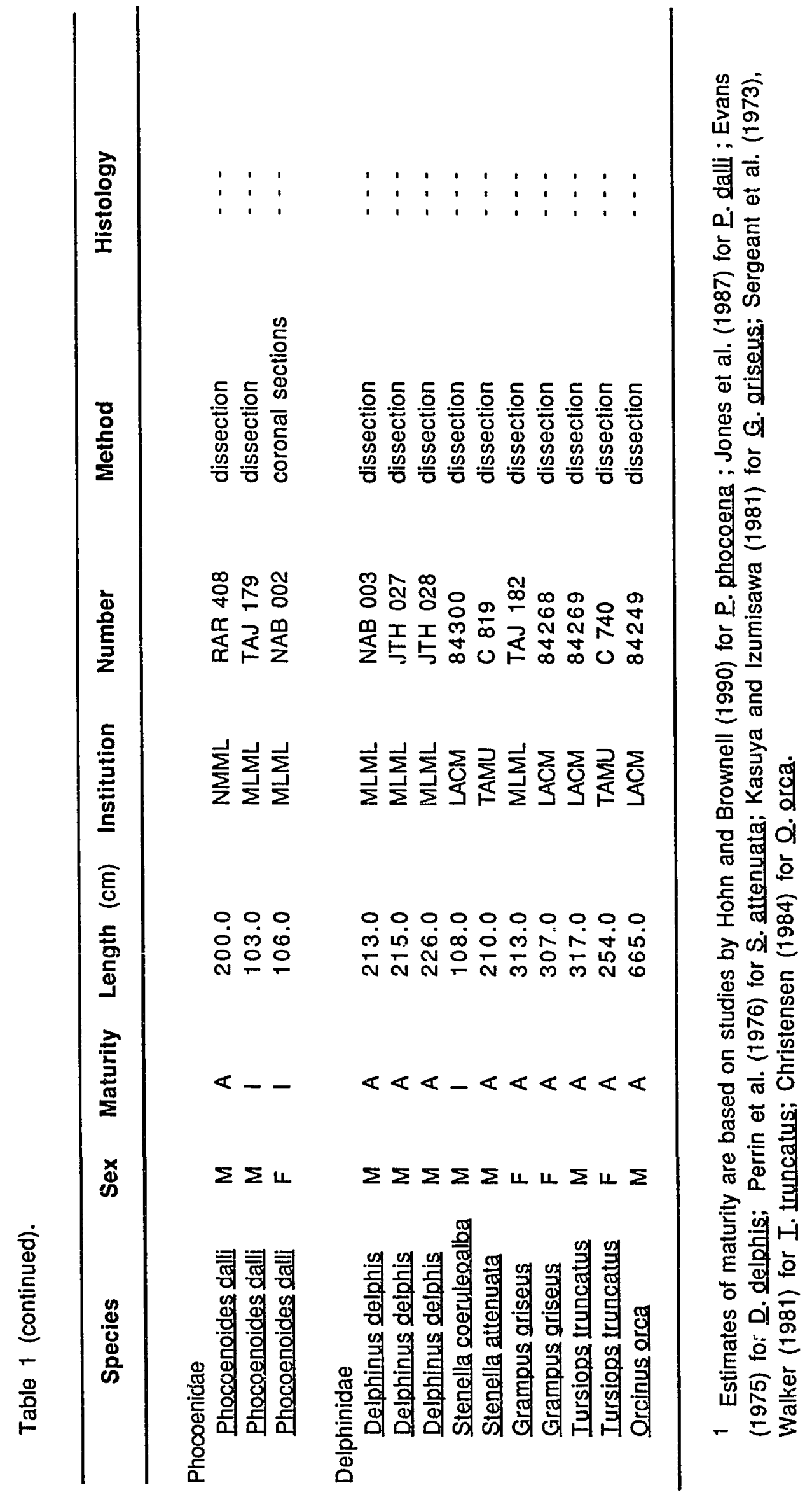




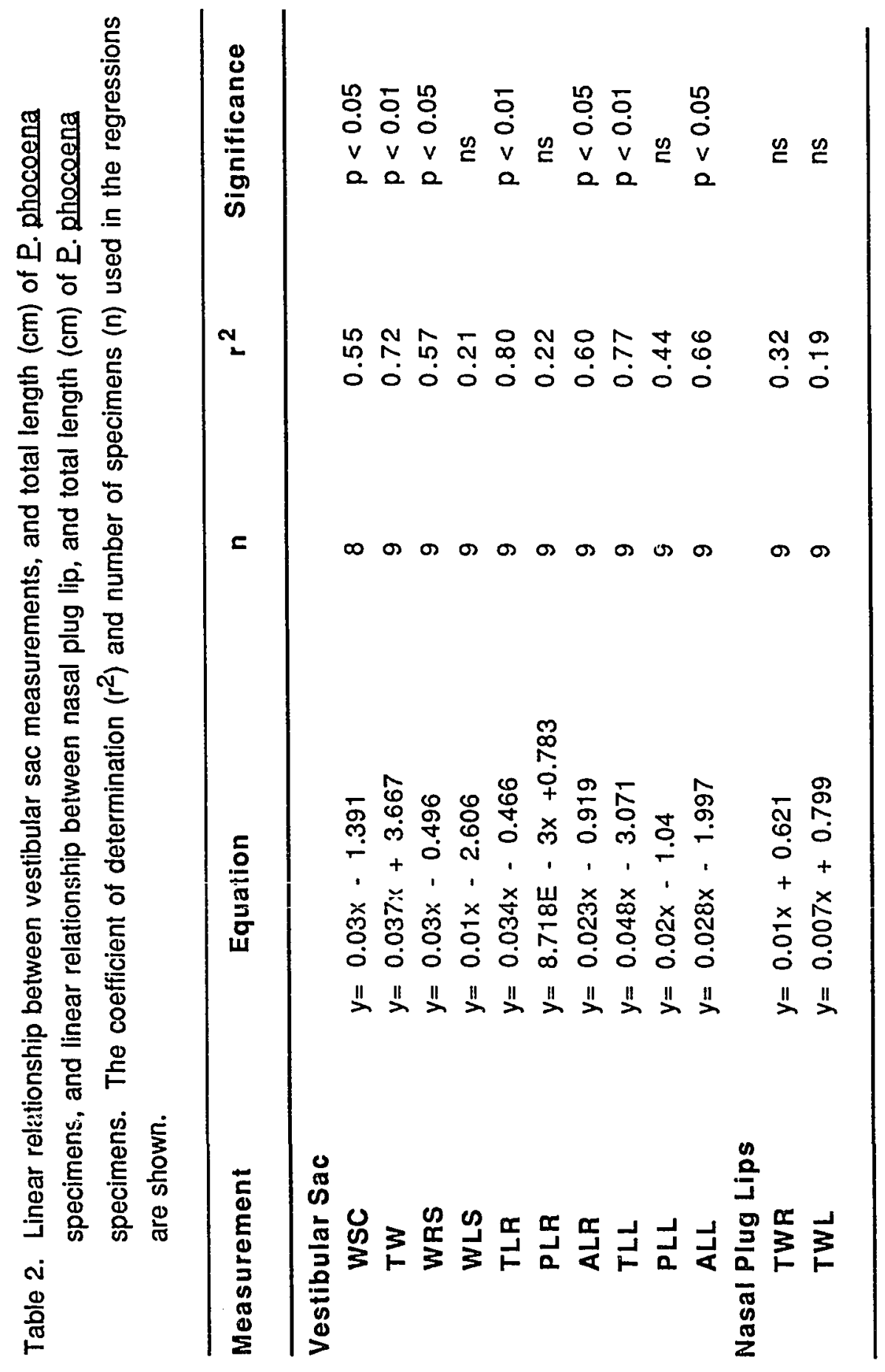




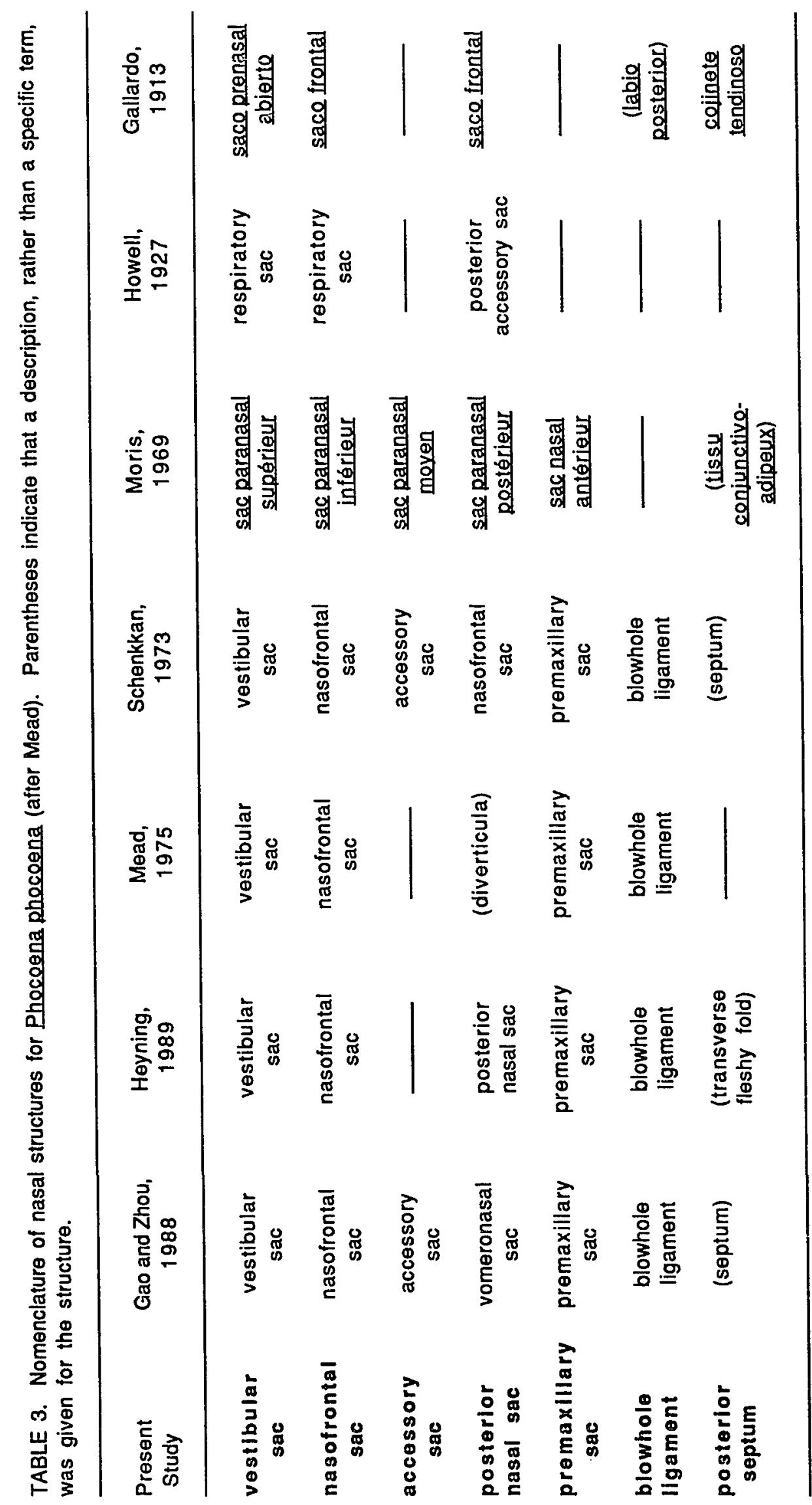




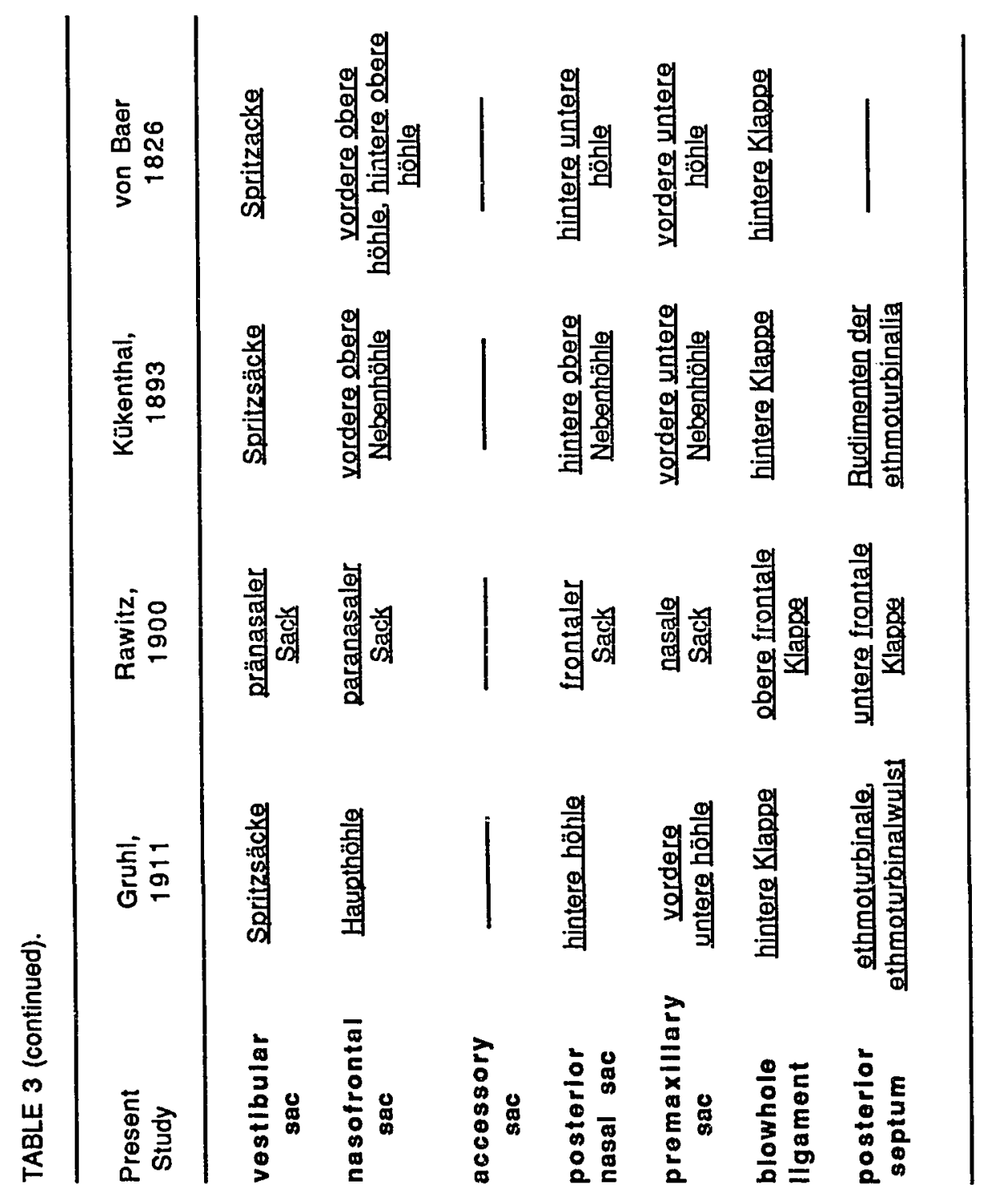




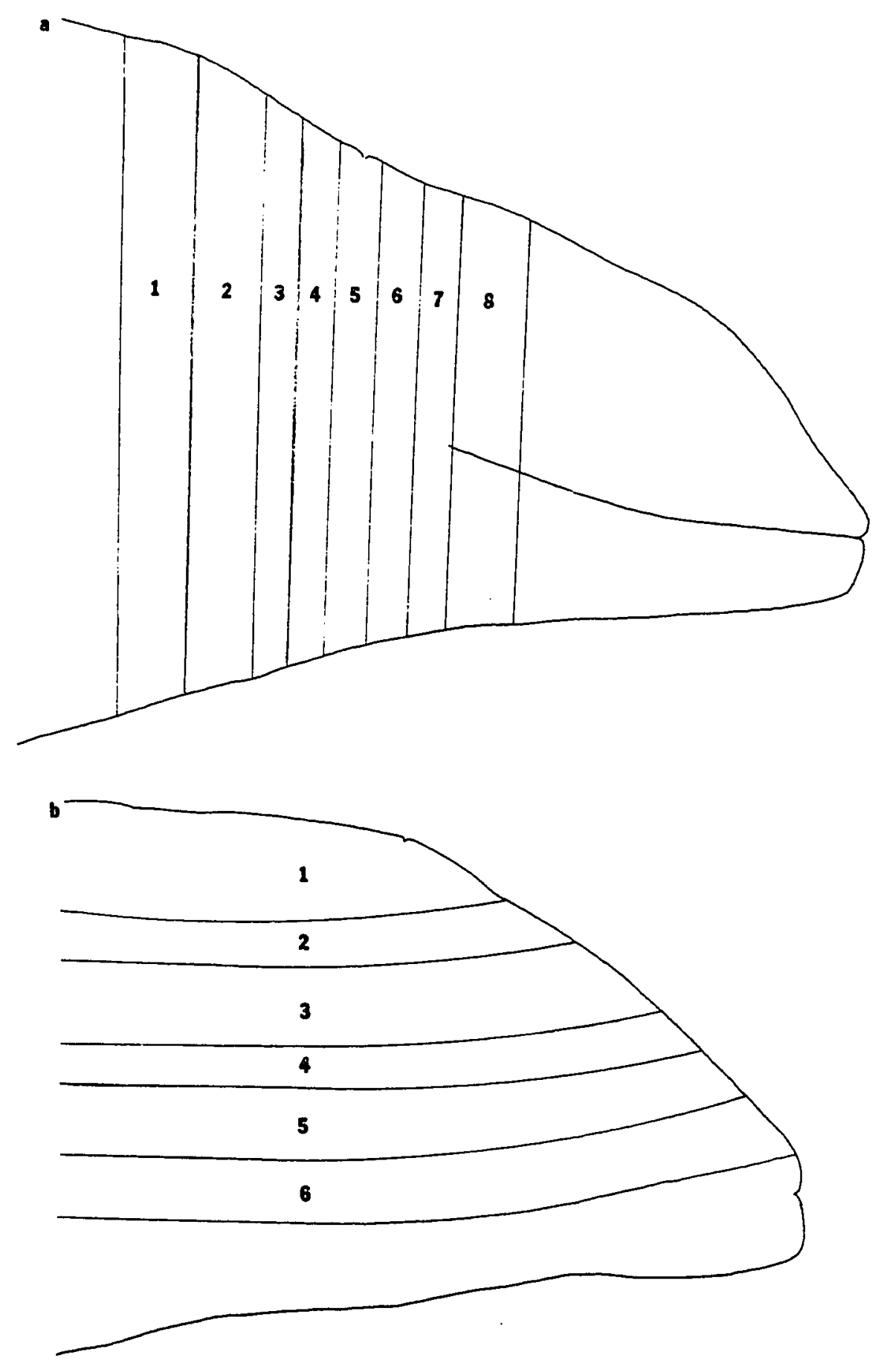

FIG 1. Representation of serial sections. a. transverse sections of $P$. phocoena (EJD 011). Sections 1,2 , and $8,2.0 \mathrm{~cm}$; sections $3-7,1.0 \mathrm{~cm}$; b. coronal sections of $P$. dalli neonate (NAB 002). Sections 3,5 , and $6,1.0 \mathrm{~cm}$; sections 2 and $4,1.0 \mathrm{~cm}$. 

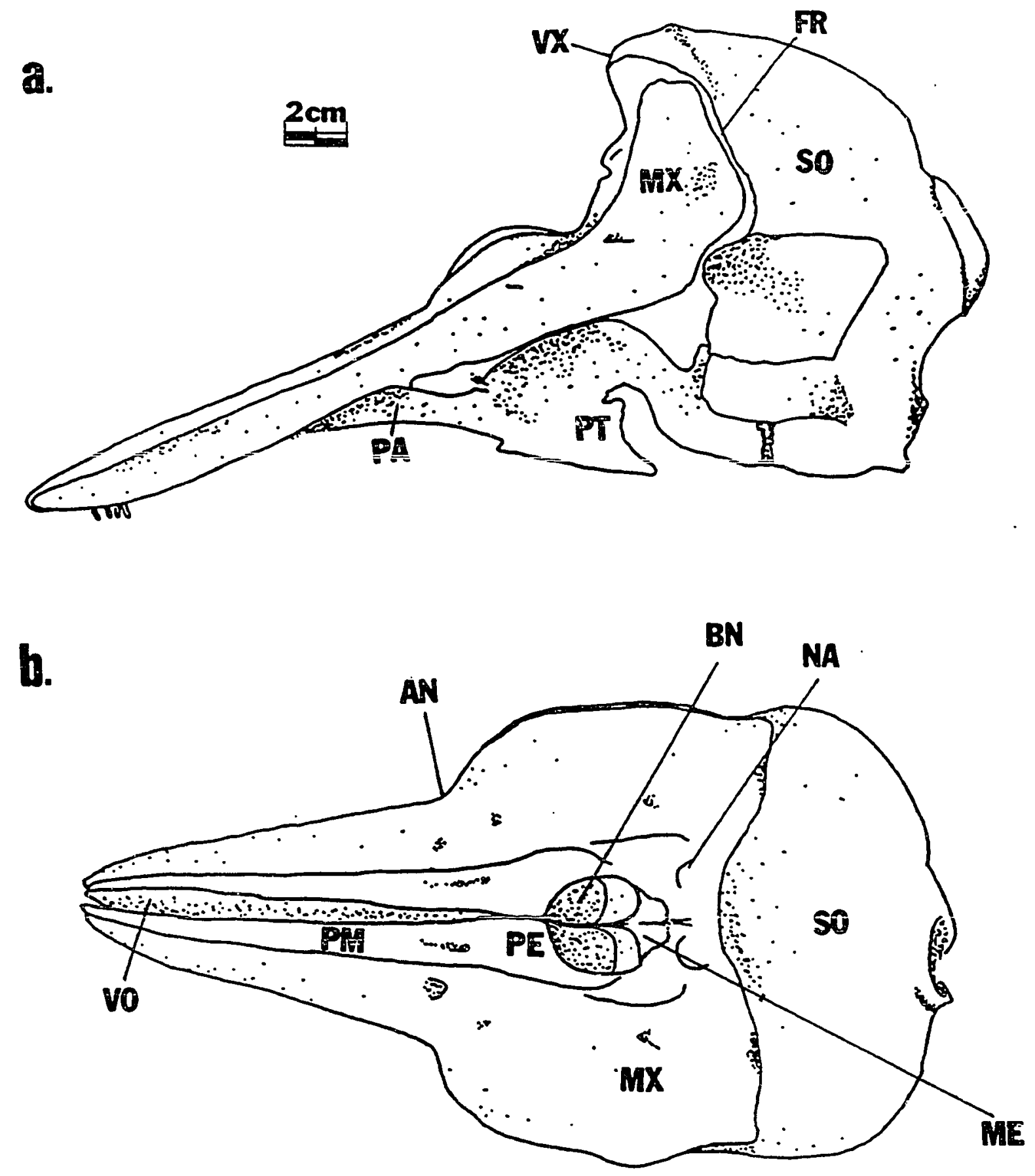

FIG. 2. a. lateral view; b. dorsal view of $P$. dalli skull (SJSU, C-116). AN, antorbital notch; BN, bony nares; ME, mesethmoid; $M X$, maxilla; NA, nasal; PA, palatine; PE, premaxillary eminence; PT, pterygoid; SO, supraoccipital; VO, vomer; VX, vertex. 


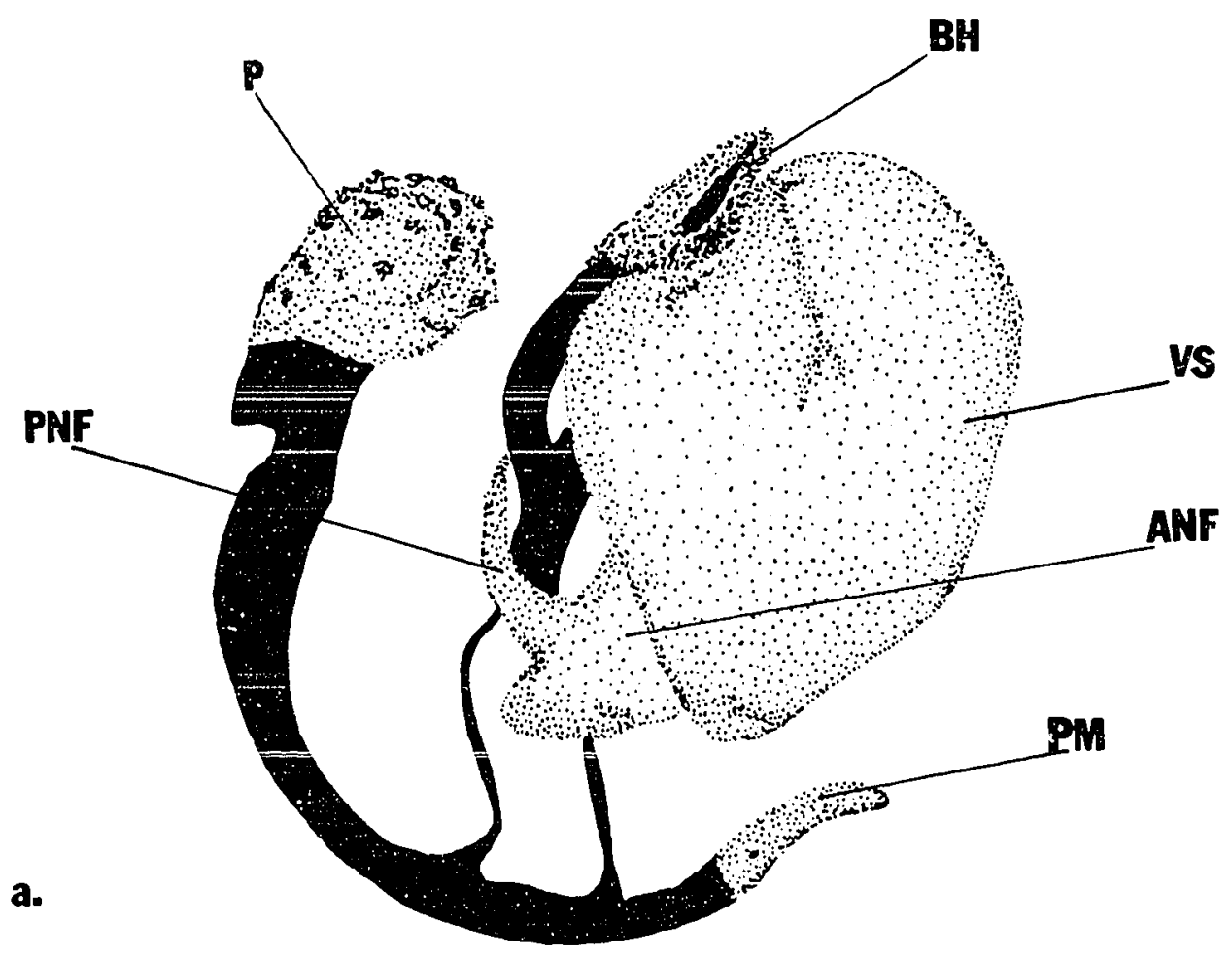

FIG. 3. a. schematic view (anterolateral) of the right nasal diverticula of $\mathrm{P}$. phocoena. b. schematic view (dorsal) of the nasal diverticula of $P$. phoceena, after Gao and Zhou (1988). BH, blowhole; VS, vestibular sac; ANF, anterior nasofrontal sac; PNF, posterior nasofrontal sac; PM, premaxillary sac; P, posterior nasal sac.

b.

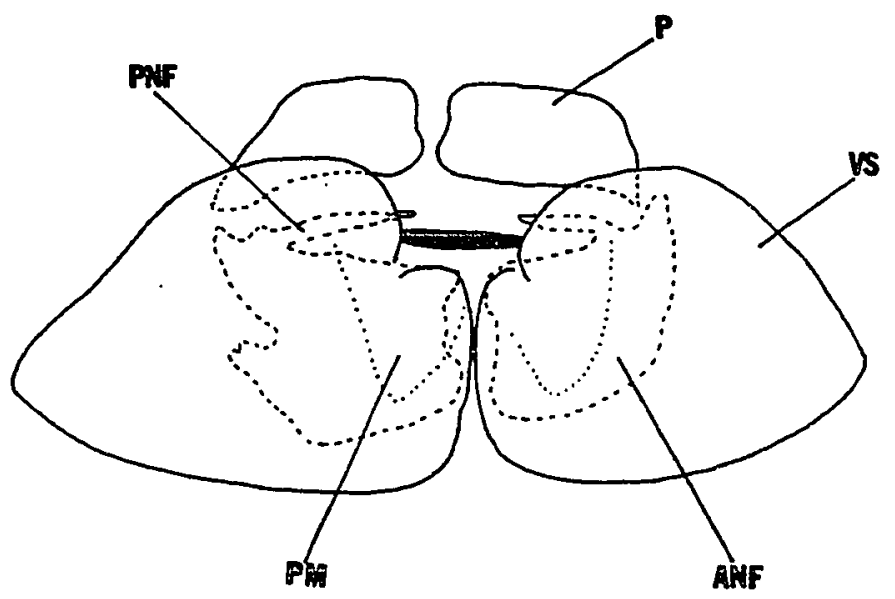




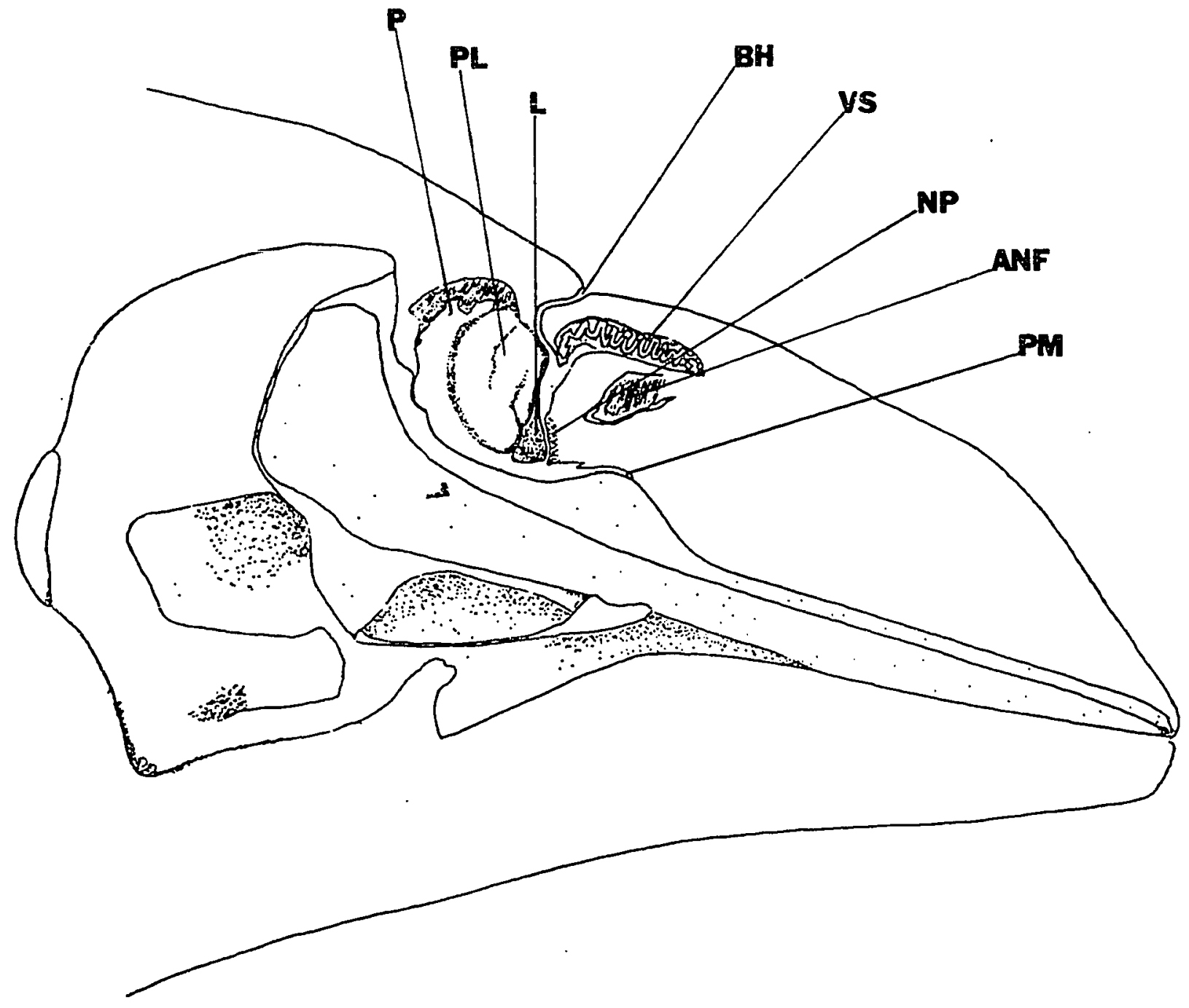

FIG. 4. Schematic view of the lateral aspect of the nasal passages of $P$. phoceena. $B H$, blowhole; VS, vestibular sac; ANF, anterior nasofrontal sac; PM, premaxillary sac; NP, nasal plug; L, blowhole ligament; PL, posterior septum of the blowhole ligament; $P$, posterior nasal sac. 


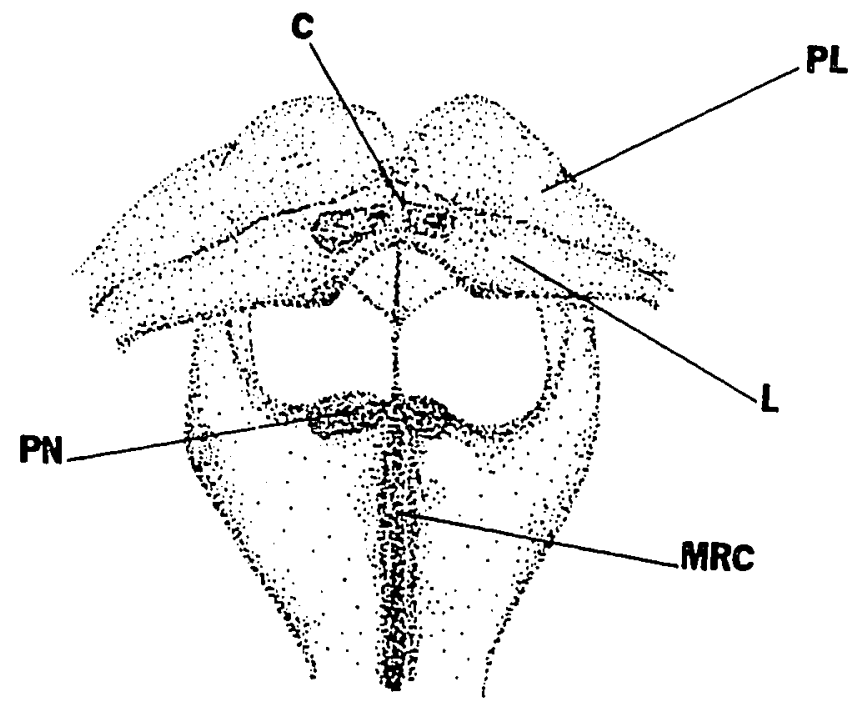

a.

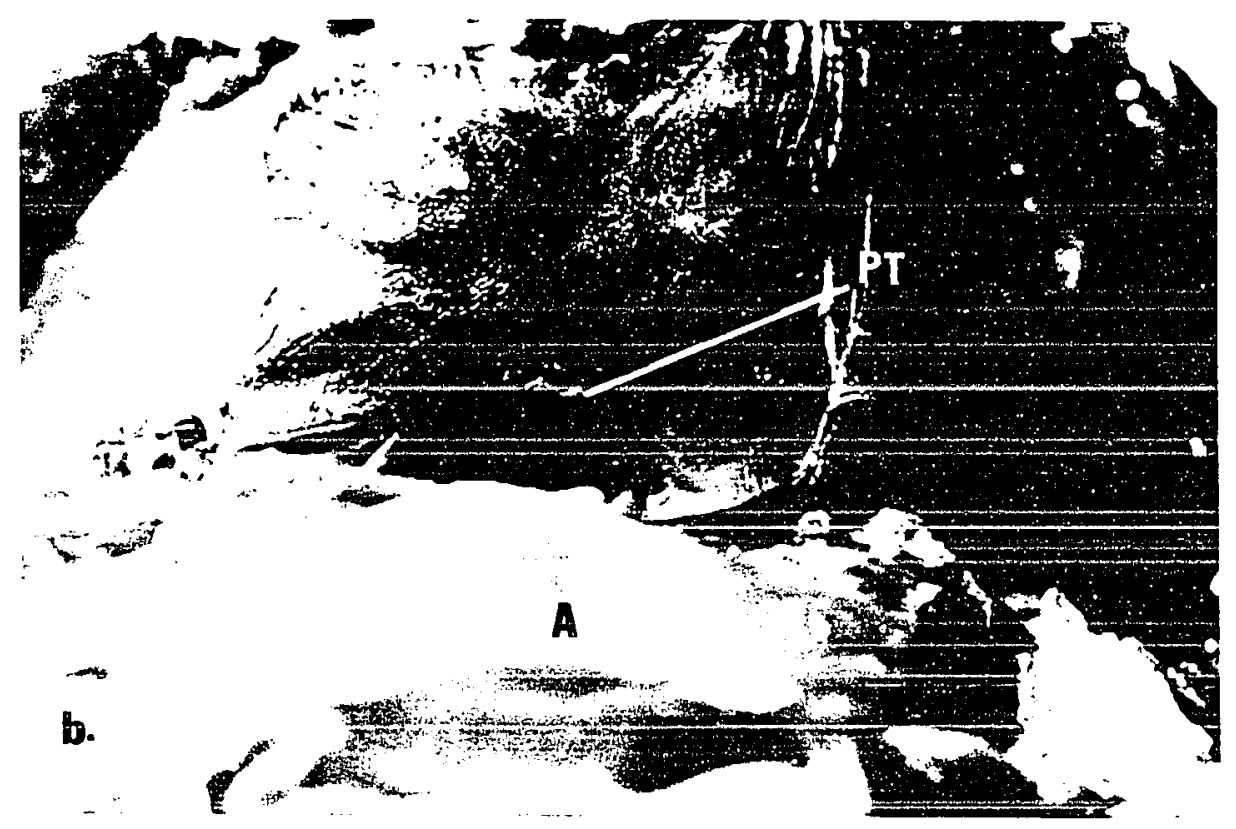

FIG. 5 a. Anterodorsal view of the blowhole ligament (L), posterior septum (PL), and the nasal cartilage. $\mathrm{C}$, ovoid cartilage and pedicle; PN, prenarial cartilage; $M R C$, mesorostral cartilage. b. Anterior view of the tip of the cartilaginous pedicle (PT), covered by pigmented epithelium, of $\mathrm{P}$. dalli (RAR 408). A, anterior. 

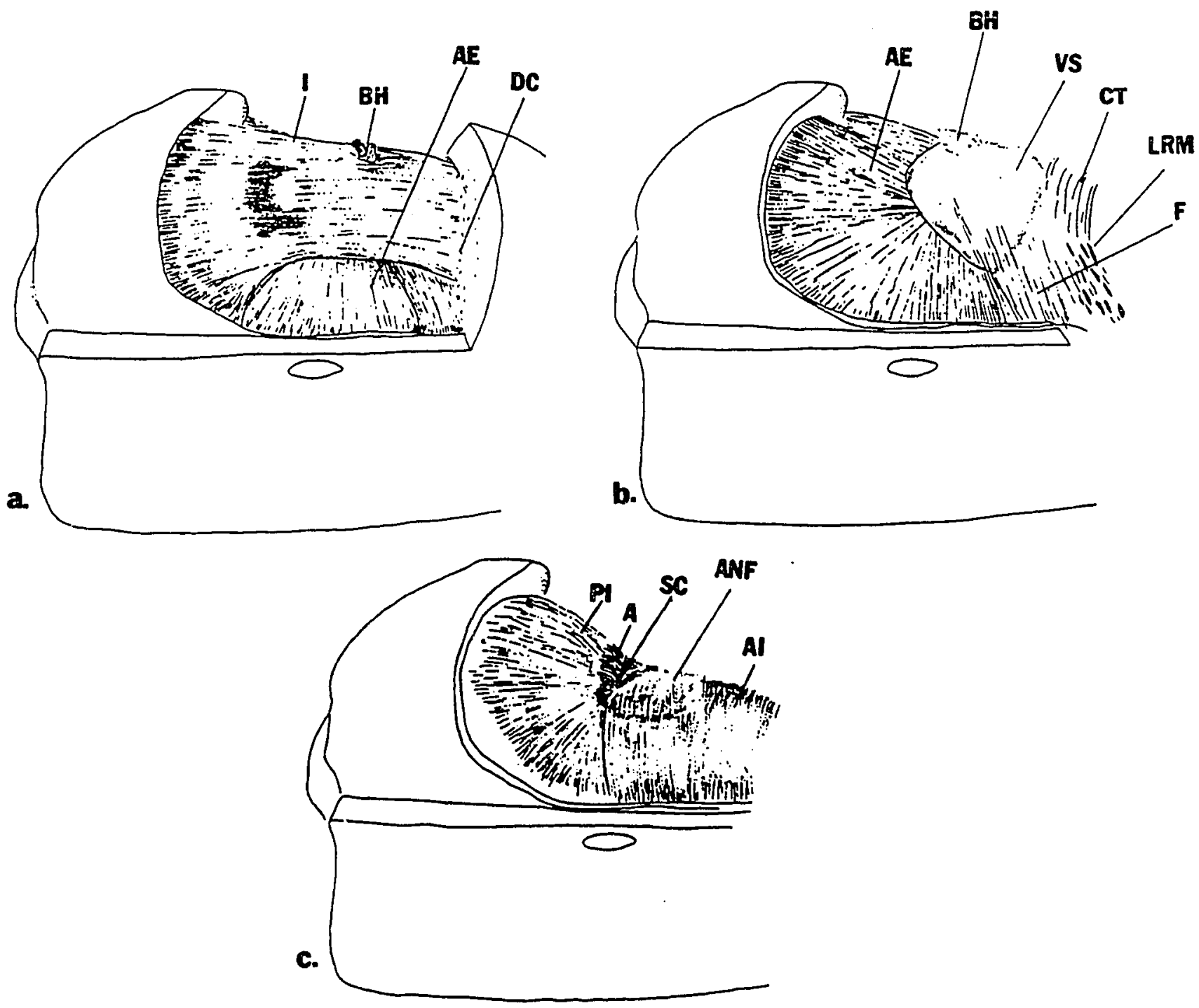

FIG. 6. a. the right pars intermedius (I) muscle of $P$. phoceena. Note tendinous portion at the posterior edge of the vestibular sac (not visible). b. the right pars anteroexternus (AE) muscle (I removed). Note the posteromedial fibers near the vertex which are difficult to separate from the overlying pars intermedius. c. the right pars posterointernus (PI) and pars anterointernus (AI) muscles (I, AE removed). $\mathrm{BH}$, blowhole; $\mathrm{DC}$, dermal connective tissue of the melon; $F$, anterior fold of pars anteroexternus merged with fibers of the pars anterointernus; VS, vestibular sac (surrounded by intrinsic muscle); LRM, lateral rostral muscle; CT, dense connective tissue; SC, spiracular cavity; A, aponeurotic fibers; ANF, anterior nasofrontal sac deep to the muscle layer. 


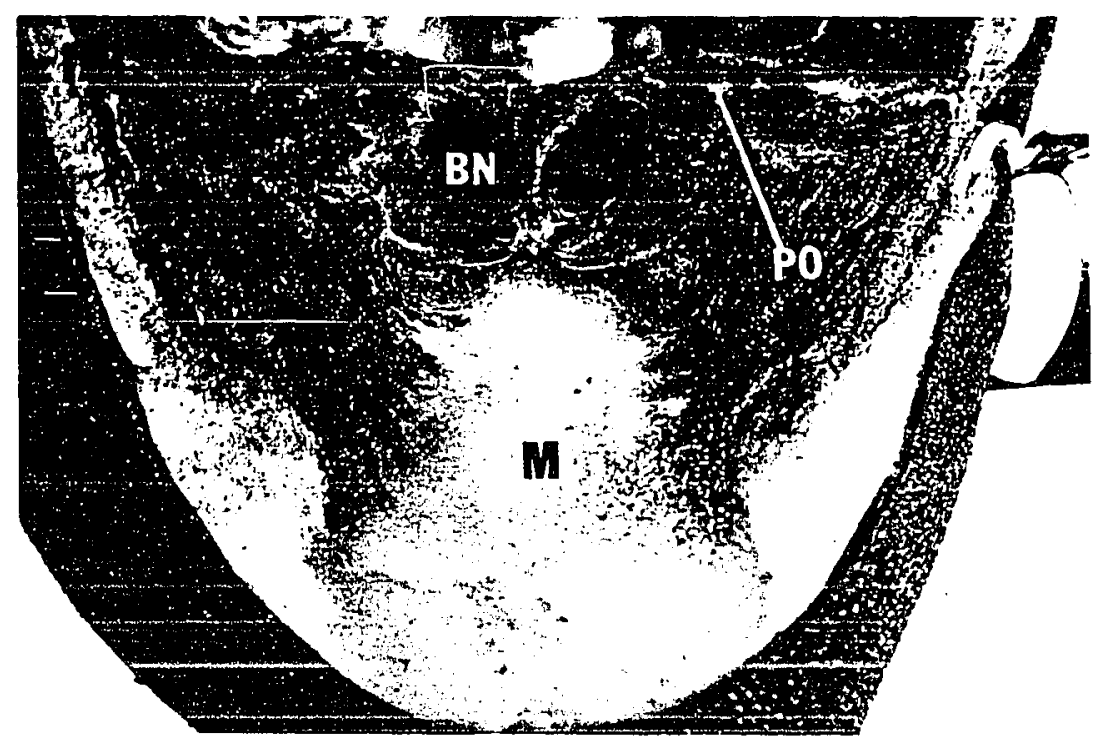

FIG. 7. Ventral aspect of section number 4 of $P$. dalli (NAB 002). M, melon; RM, rosiral musculature; BN, bony nares; PO, pre-orbital lobe of air sinus system. 


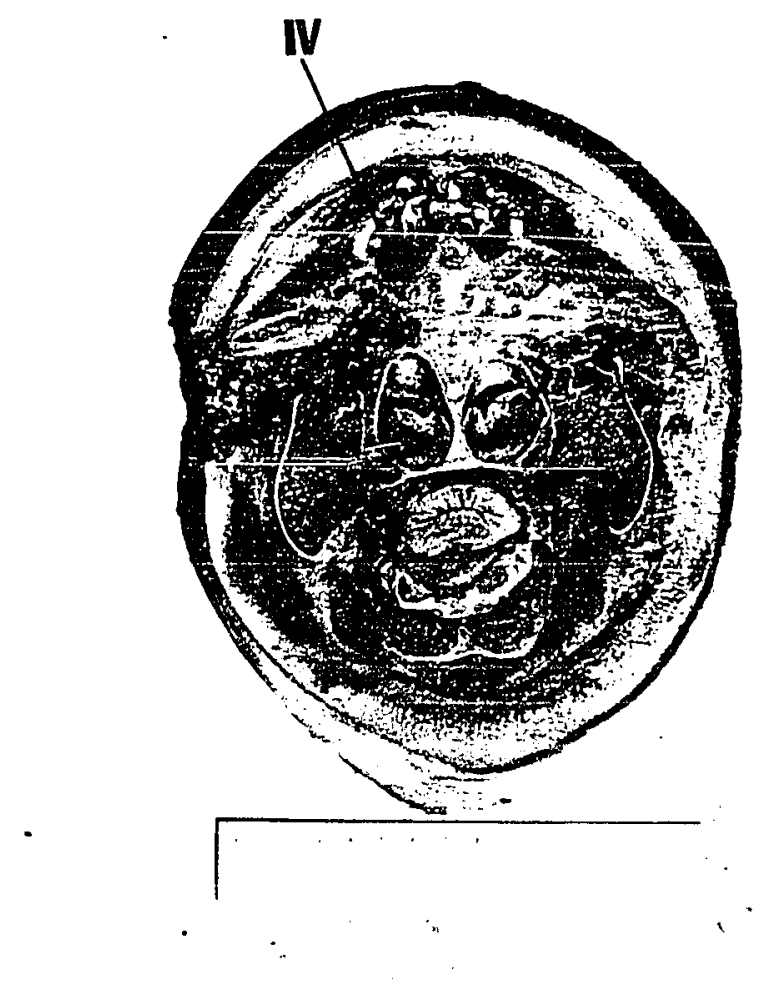

FIG 8. Anterior aspect of section number 2 of $P$. phocoena (EJD 011). IV, inferior vestibule. 


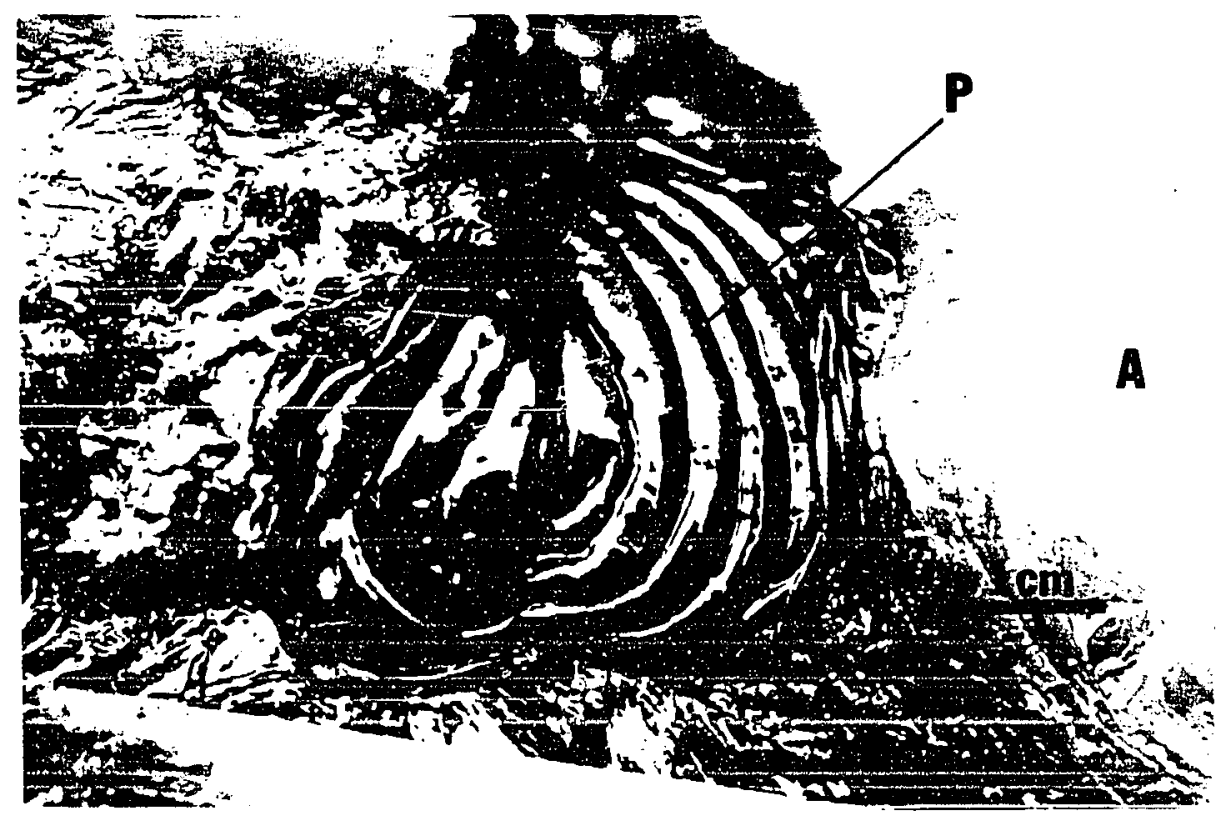

FIG. 9. Ventral surface of the right vestibular sac of $\mathrm{E}$. phocoena (LACM 84288). A, anterior; P, plica. 


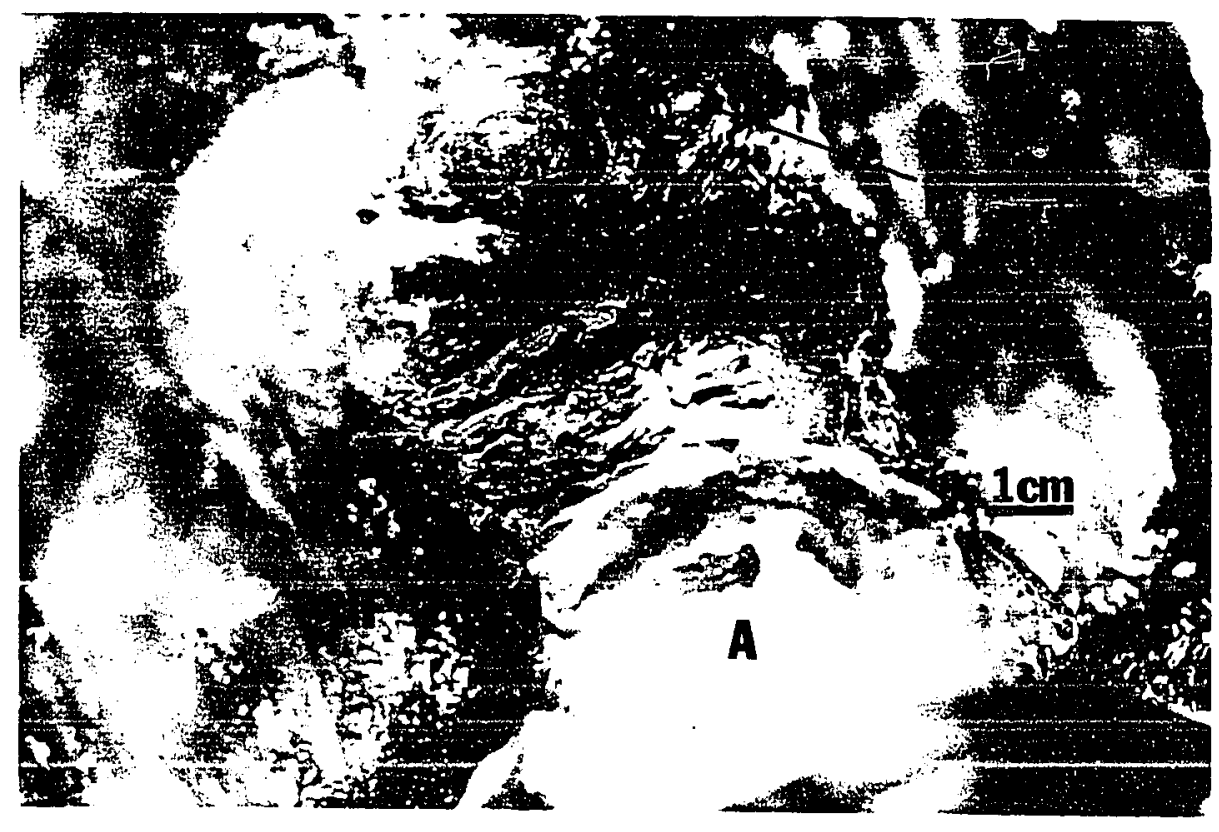

FIG. 10. Anterodorsal view of the nasofrontal sacs (ANF) arid posterior nasal sacs (P) of P. phocoena (NAB 011). Note the intrinsic muscle, and lobules present on the anterior nasofrontal sacs. A, anterior. 


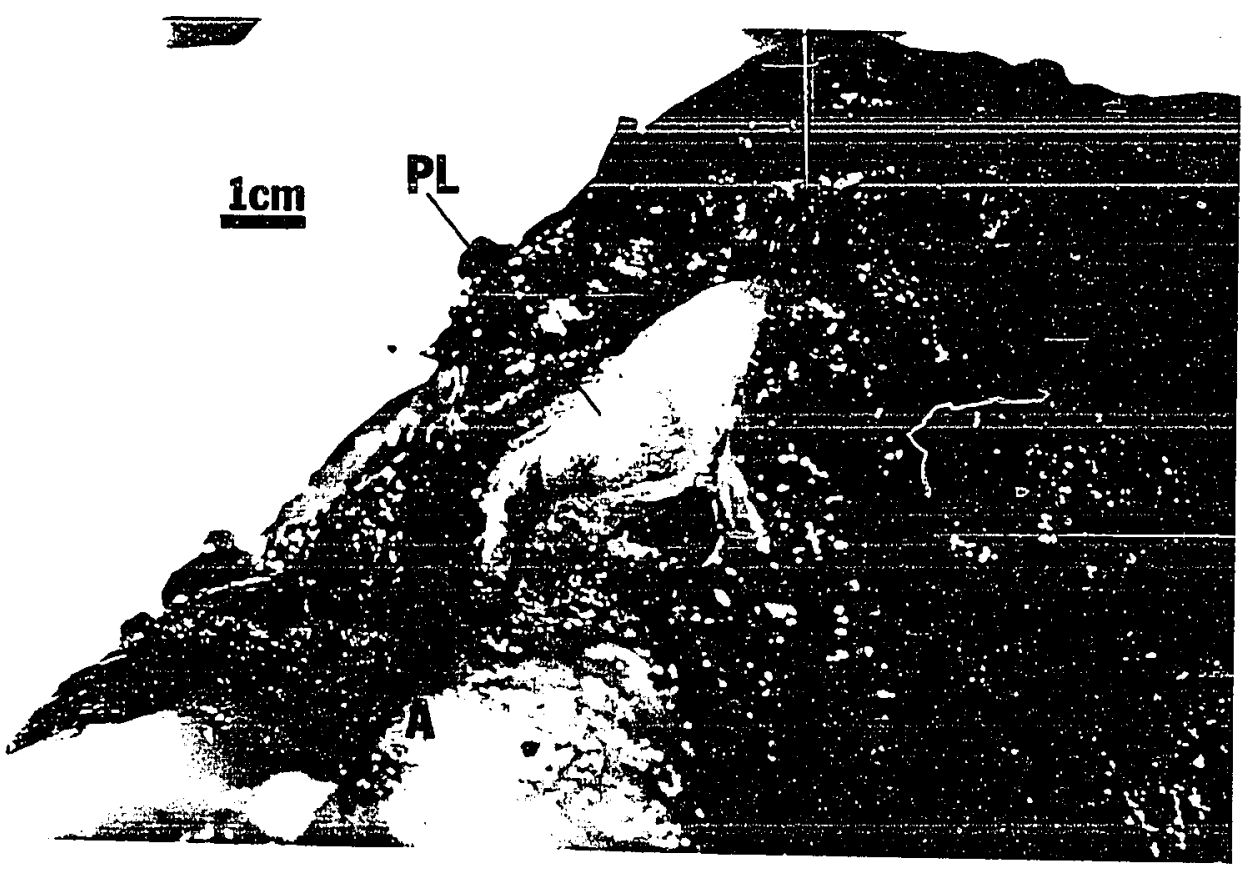

FIG. 11. Right posterior septum of the blowhole ligament (PL) of $P$. phocoena (TRK 108) with its branch on the ventral surface of the nasofrontal sac angle exposed. $A$, anterior. 


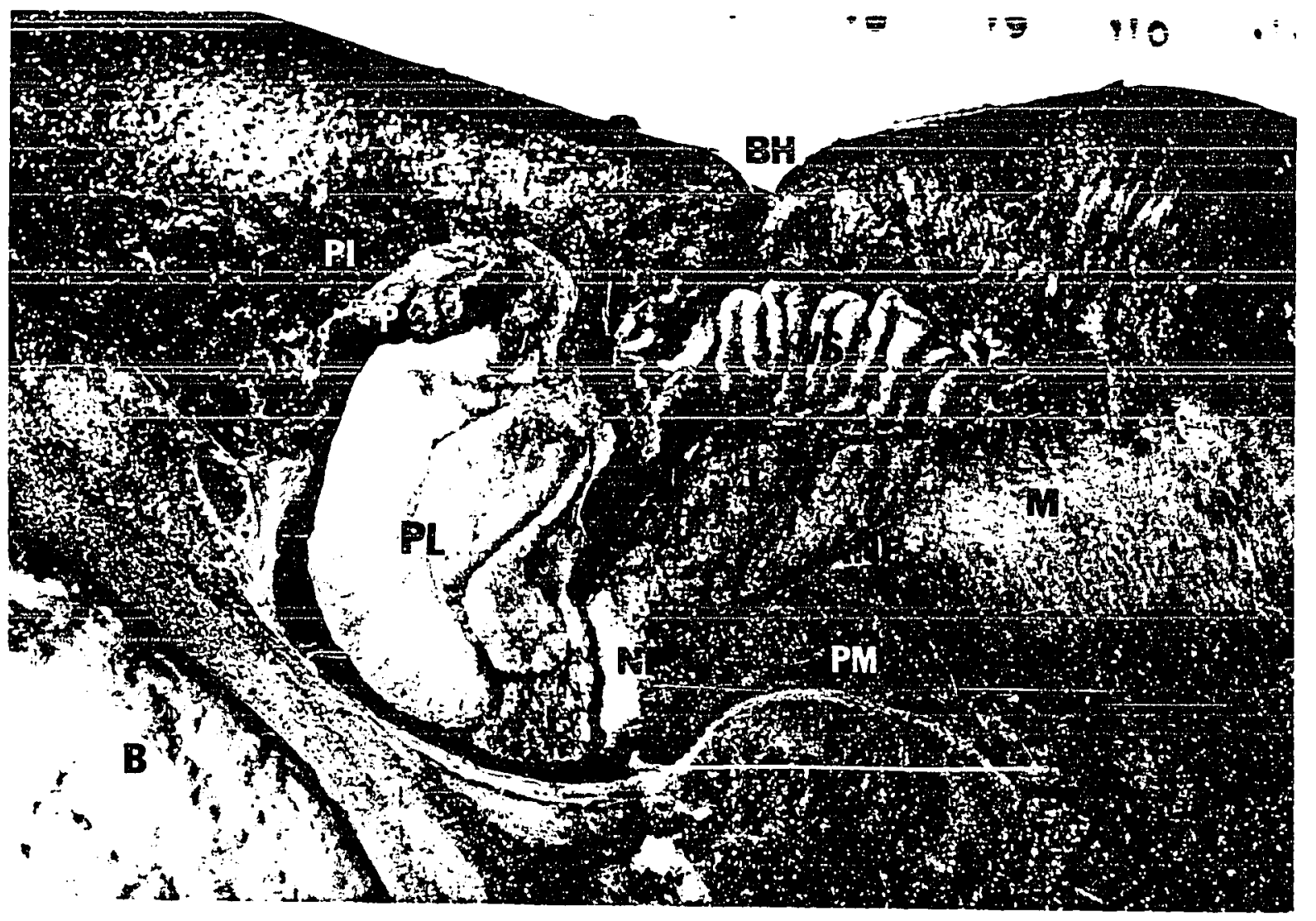

FIG 12. Lateral view of parasagittal section $1.0 \mathrm{~cm}$ from the center of head (relative to occipital condyle center)(JTH 054). Note insertion of the pars pesterointerus (PI) upon the posterior nasal sac $(P)$. BH, blowhole; VS, vestibular sac, ANF, anterior nasofrontal sac; PM, premaxillary sac; NP, nasal plug. $L$, blowhole ligament, PL, posterior septum of the blowhole ligament; $M$, melon, B, Brain. 


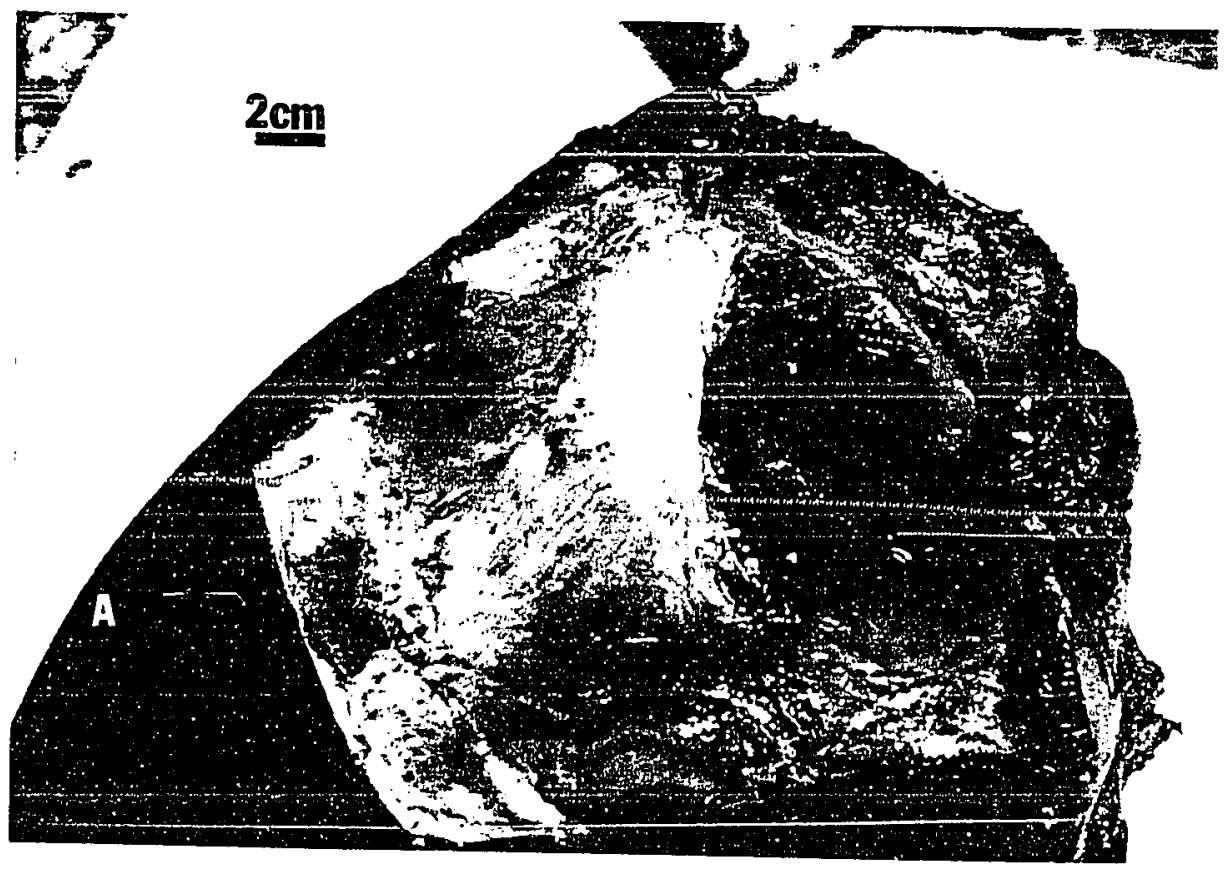

FIG 13. Lateral view oi the band of connective tissue fibers on the left side of a $P$. phocoena head (NAB 011). A, anterior; V, vertex; SP, supraorbital process. 


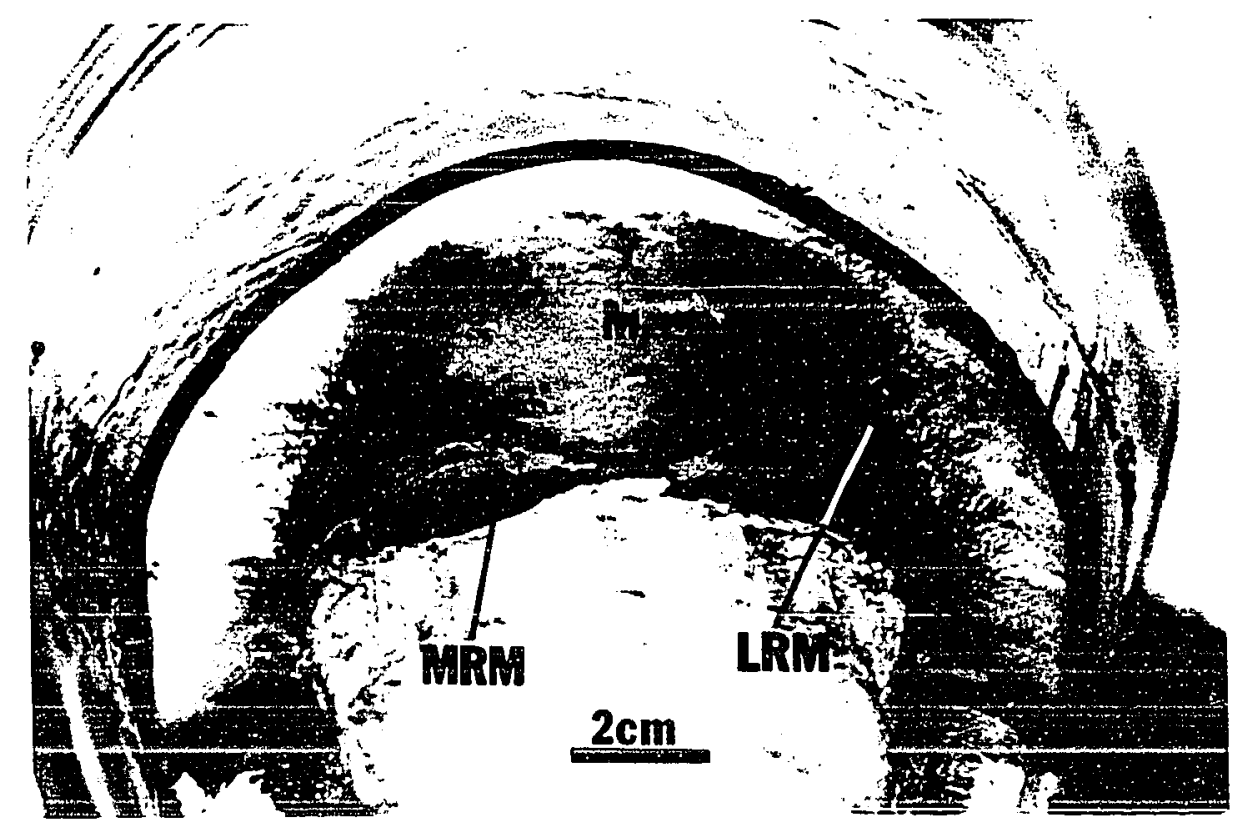

FIG. 14. Anterior view of lateral (LRM) and medial rostral muscles (MRM) $10.0 \mathrm{~cm}$ from rostrum tip of $P$. phoceena (NAB 010). $M$, melon. 


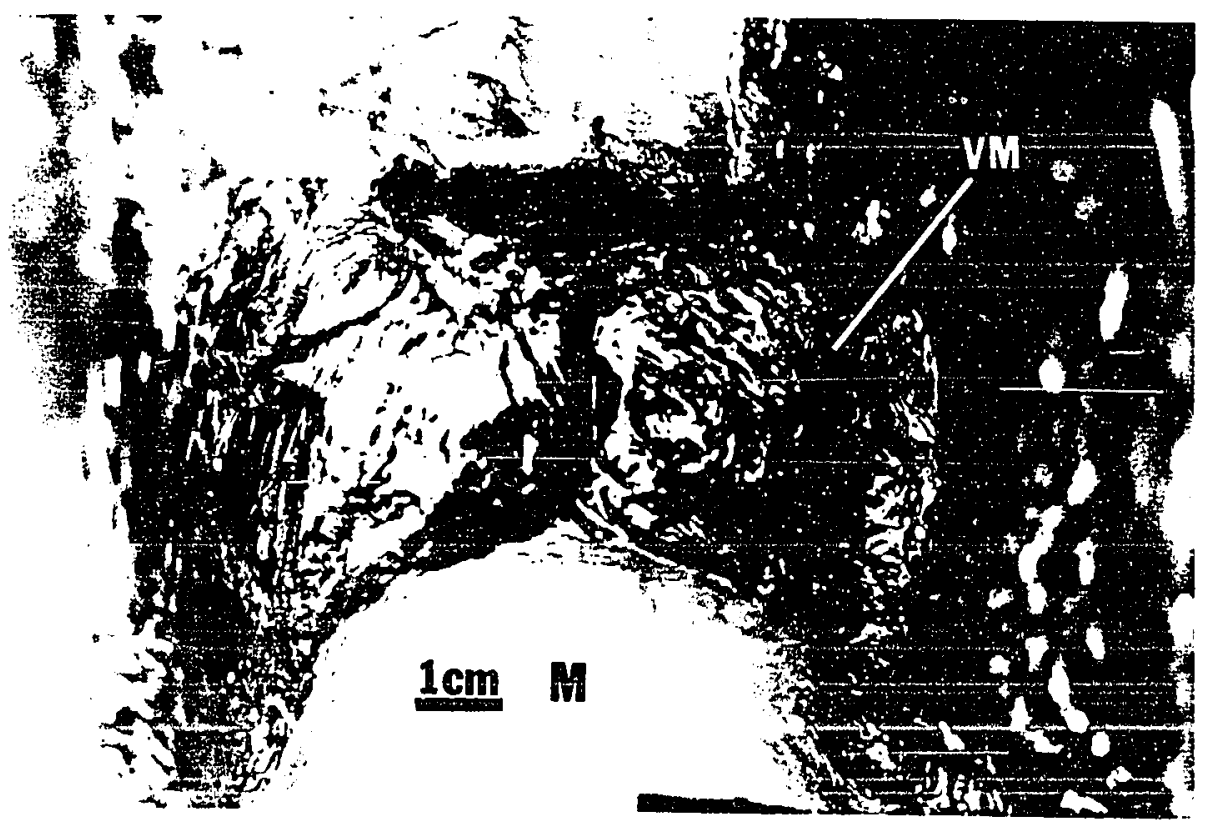

FIG 15. Anterodorsal view of the vestibular sac intrinsic muscle of P. phecoene (LACM! 84288) Note position over the posterior tip of the melon. VM, vestibular sac intrinsic muscle; $M$, Melon. 


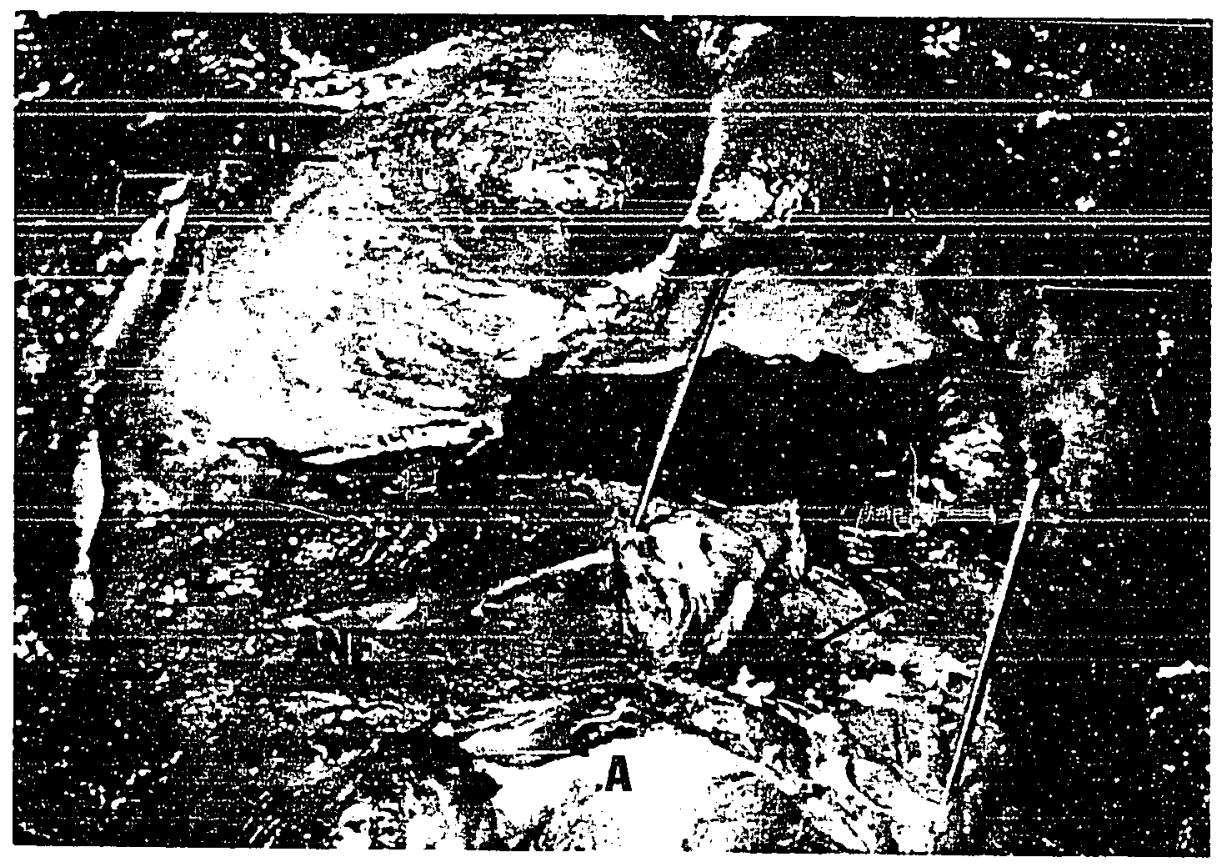

FIG. 16. Anterodorsal view of the nasofronta! sacs and posterior nasal sacs of P. dalli (RAR 408). The lumen of the left anterior nasofrontal sac is exposed, showing nasal sac calculi (CA) and crescentic pores. A, anterior; ANF, anterior nasofrontal sac (right). 


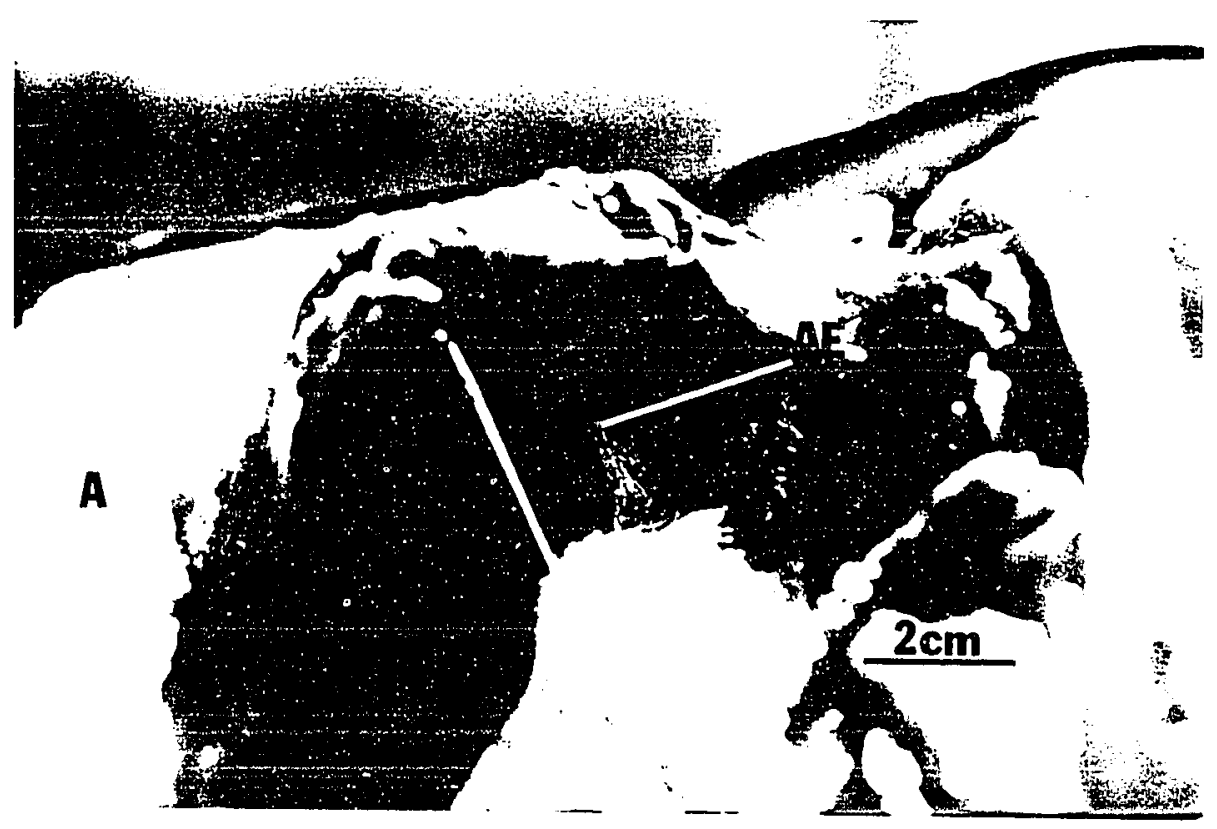

FIG. 17. Lateroventral view of the fibers of the pars anteroexternus (AE) inserting upon the left vestihular sac aperture of $\underline{P}$. dalli (RAR 408). A, anterior. 

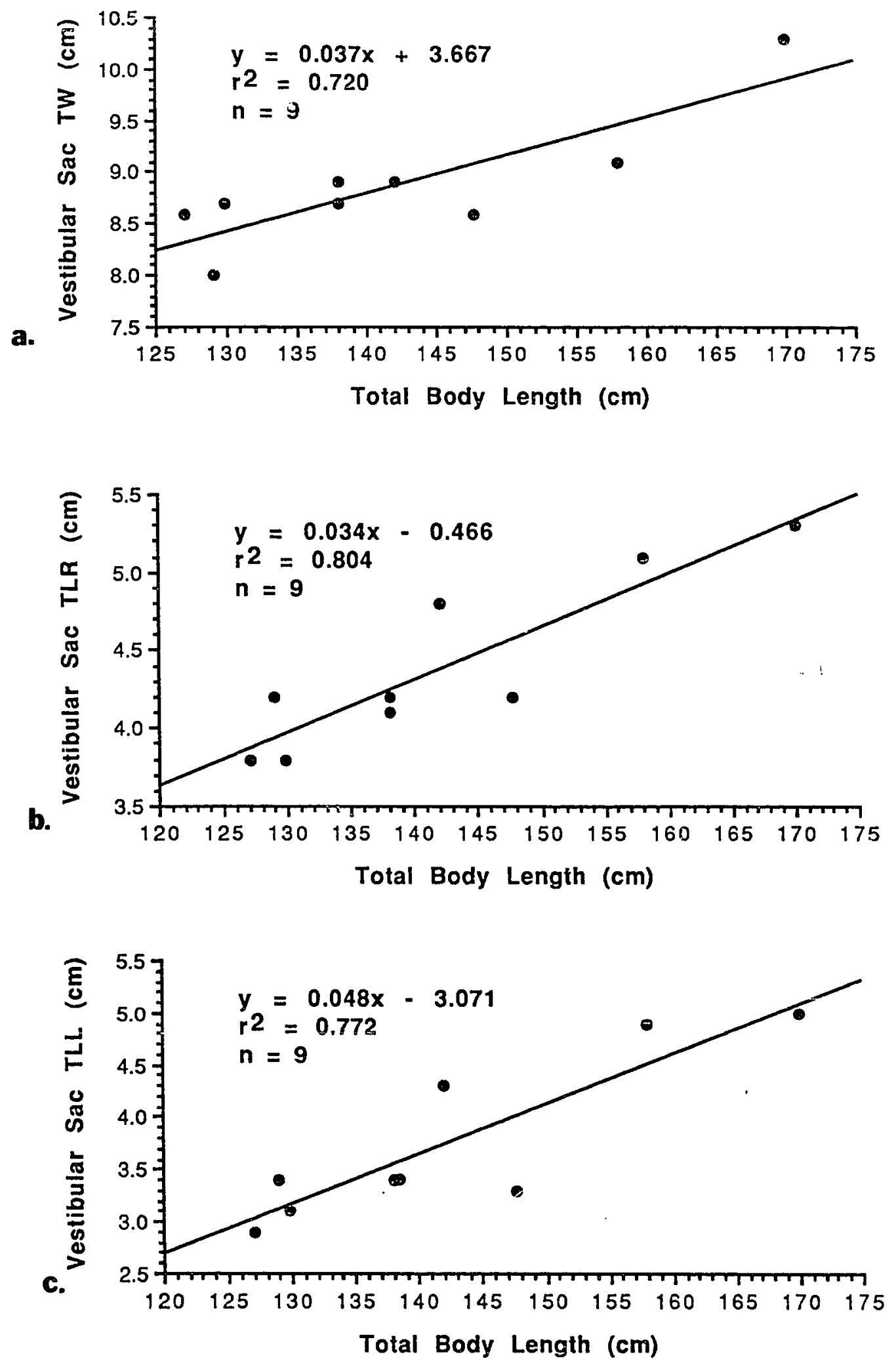

FIG. 18. Scatterplot of the relationship between a. vestibular sac total width (TW), b. vestibular sac total length right (TLR), c. vestibular sac total length left (TLL), and total body length $(\mathrm{cm})$ of $P$. phocoena. 


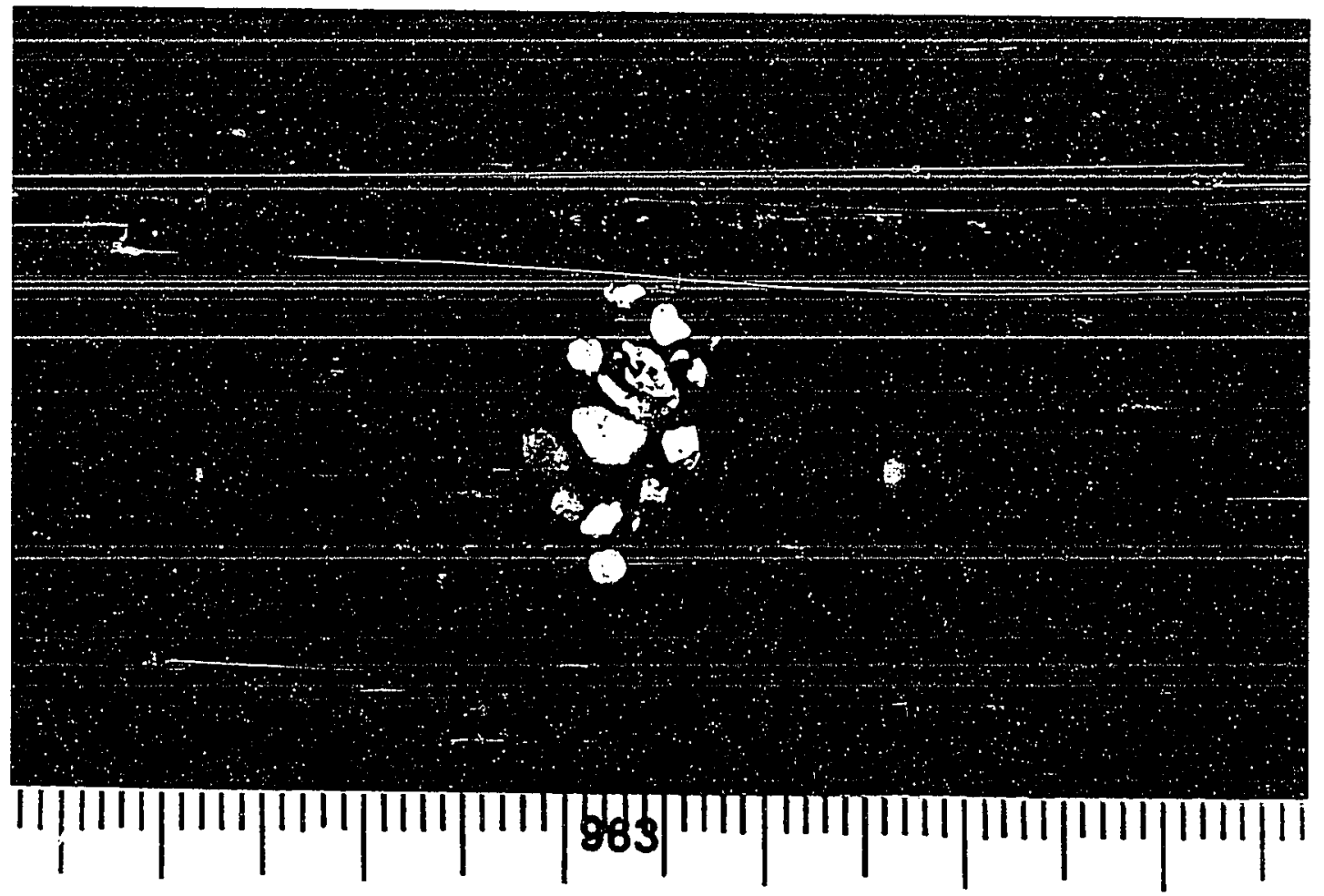

FIG. 19. Nasal sac calculi found in the anterior nasofrontal sacs and the right posterior nasal sac of Phocoenoides dalli (MJH 073). 


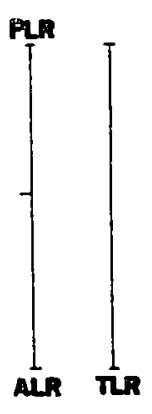

a.

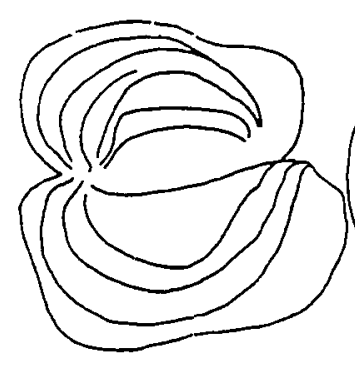

Wse

wrS
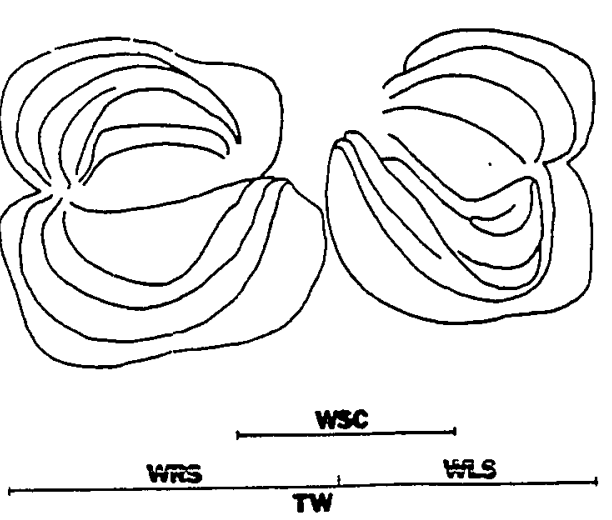

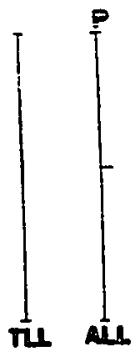

C.

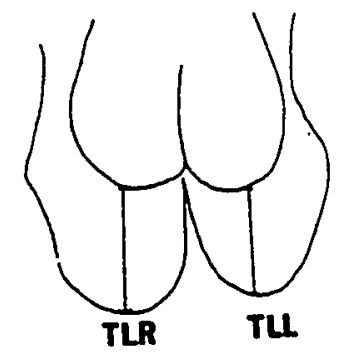

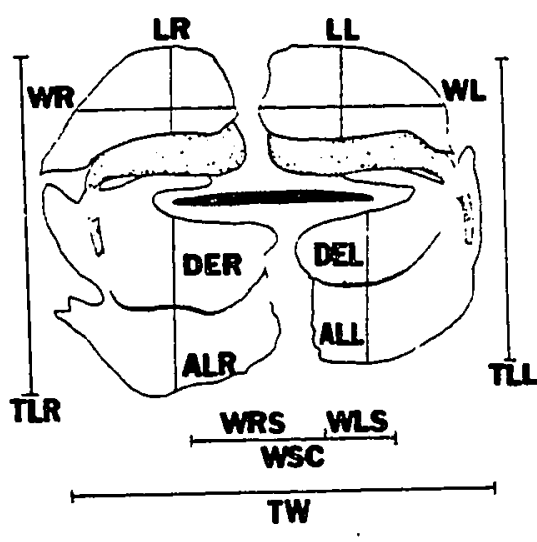

d.

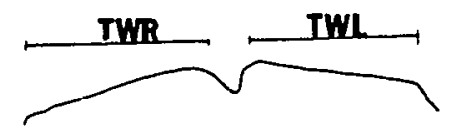

Appendix 1. Diagrams of measurements used in the present study. a. ventral surface of vestibuiar sacs. b. nasofrontal sacs and posterior nasal sacs. c. ventral surface of premaxillary sacs. d. nasal plugs.

WSC $=$ width spiracular cavity

WRS $=$ width right oi nasal septum.

TLR $=$ total lengtit of right sac.

$A L R=$ length of anterior part of right sac. PLR= length of posterior part of right sac

$P L L=$ length of posterior part of left sac.

$A L R=$ length of right anterior component.

DER = length of right dorsal expansion.

WRA $=$ width of angle of right sac.

LR= tolal length right posterior nasal sac.

$W R=$ total width right posterior nasal sac.

TWR $=$ total width right.
$T W=$ total width of vestibular sacs.

WLS $=$ width left of nasal septum.

$T L L=$ total length of ieft sac.

$A L L=$ length of anterior part of left sac.

$A L L=$ length of left anterior component.

DEL= length of left dorsal expansion.

$W L A=$ width of angle of left sac.

$L L=$ total length of left posterior nasal sac.

$W L=$ total width left posterior nasal sac.

$T W L=$ total width left 


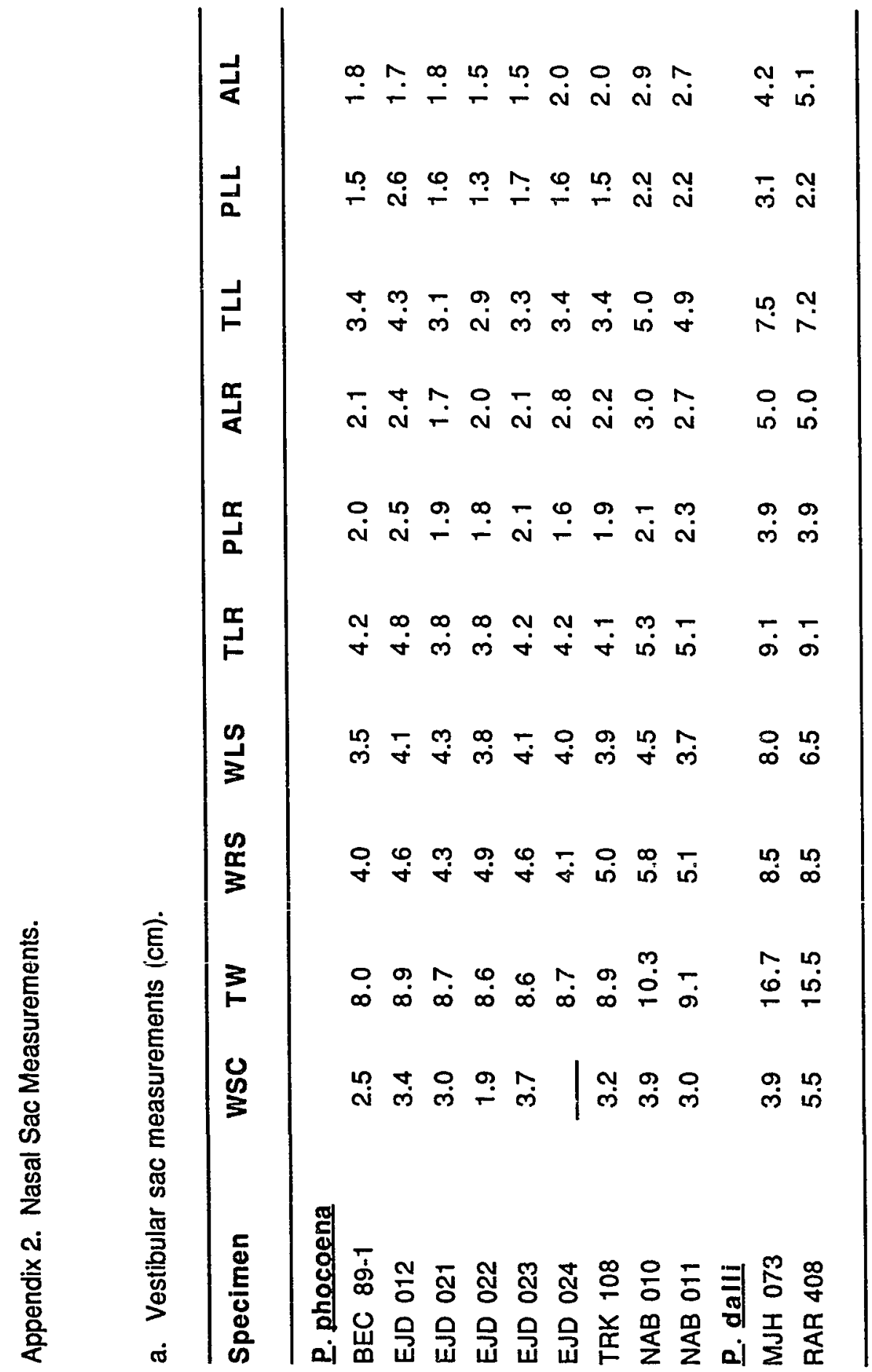




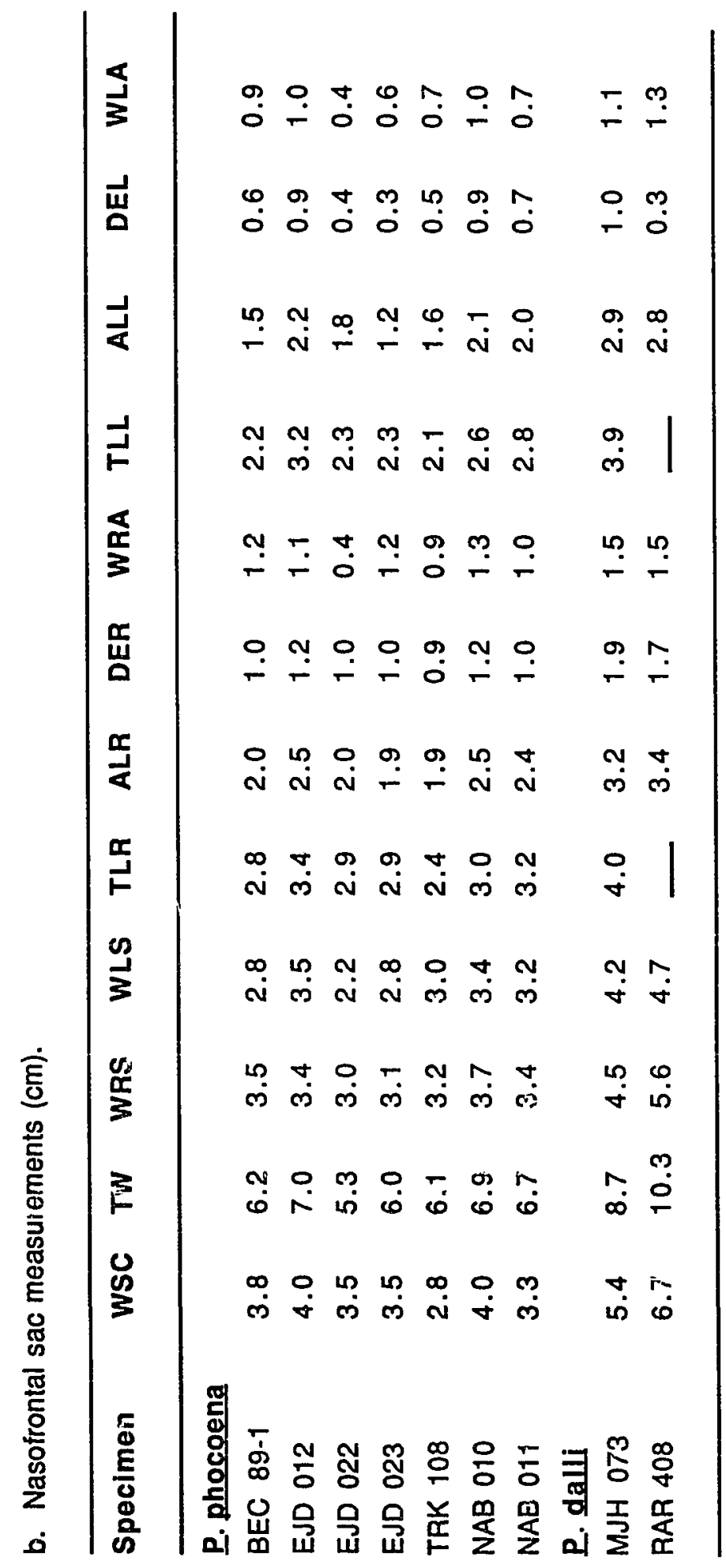




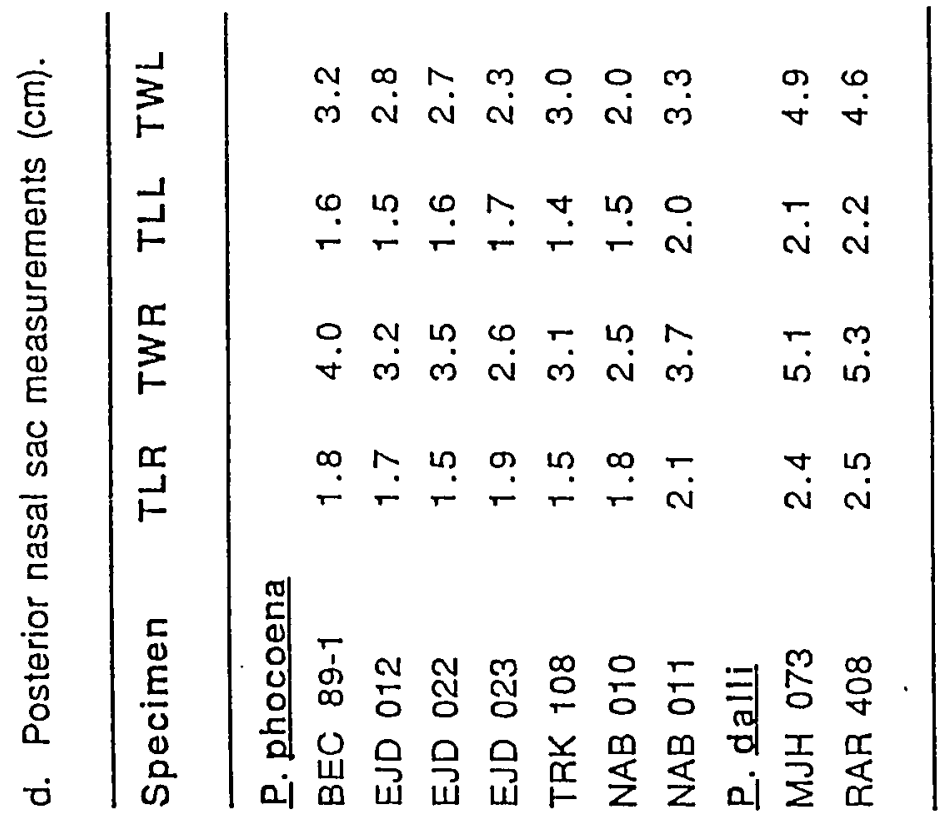

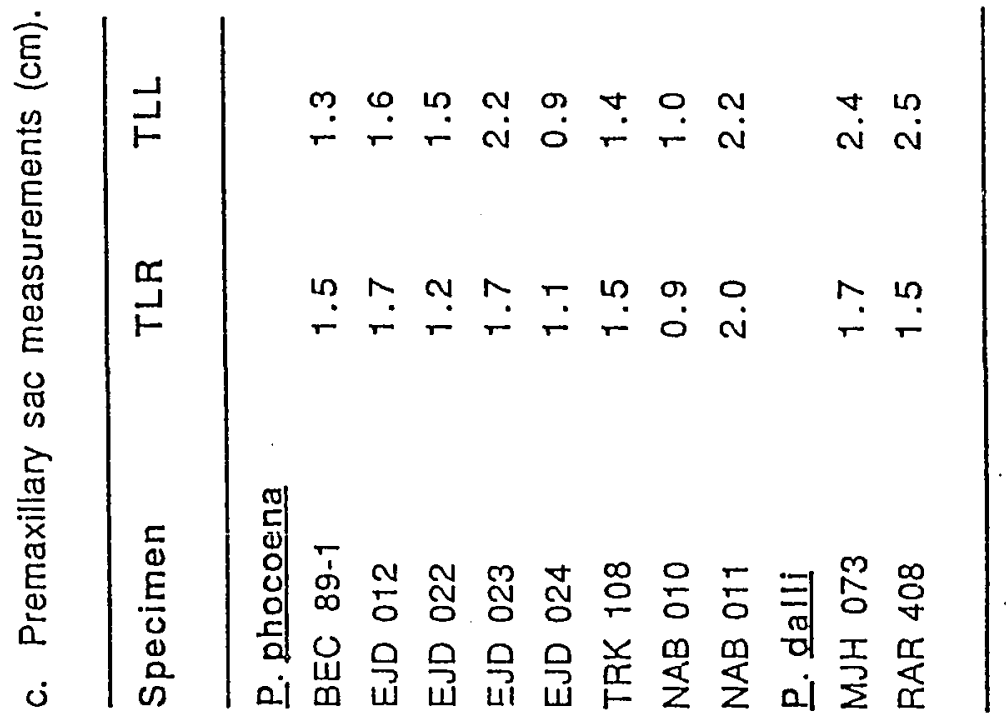




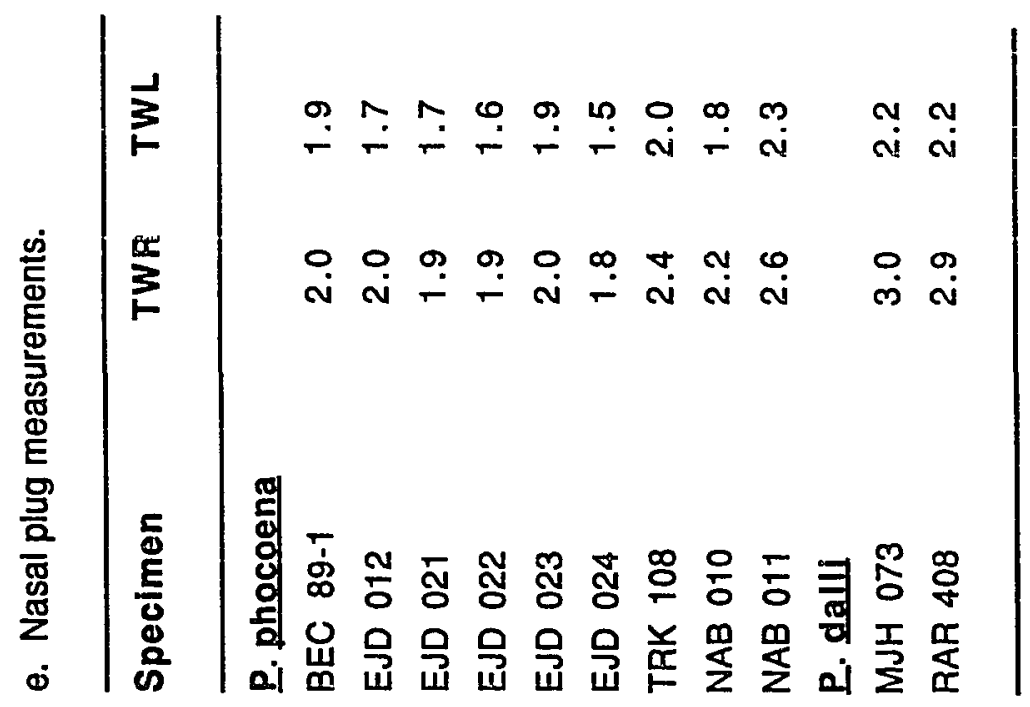

